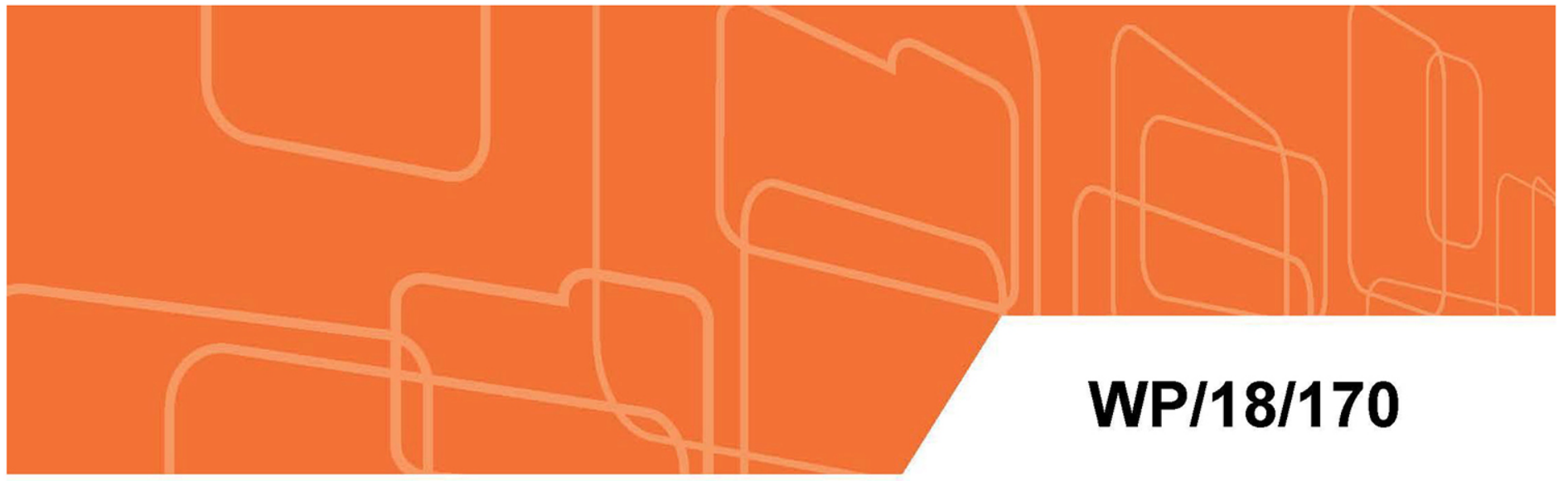

\title{
Twin Deficits in Developing Economies
}

by Davide Furceri and Aleksandra Zdzienicka

IMF Working Papers describe research in progress by the author(s) and are published to elicit comments and to encourage debate. The views expressed in IMF Working Papers are those of the author(s) and do not necessarily represent the views of the IMF, its Executive Board, or IMF management. 


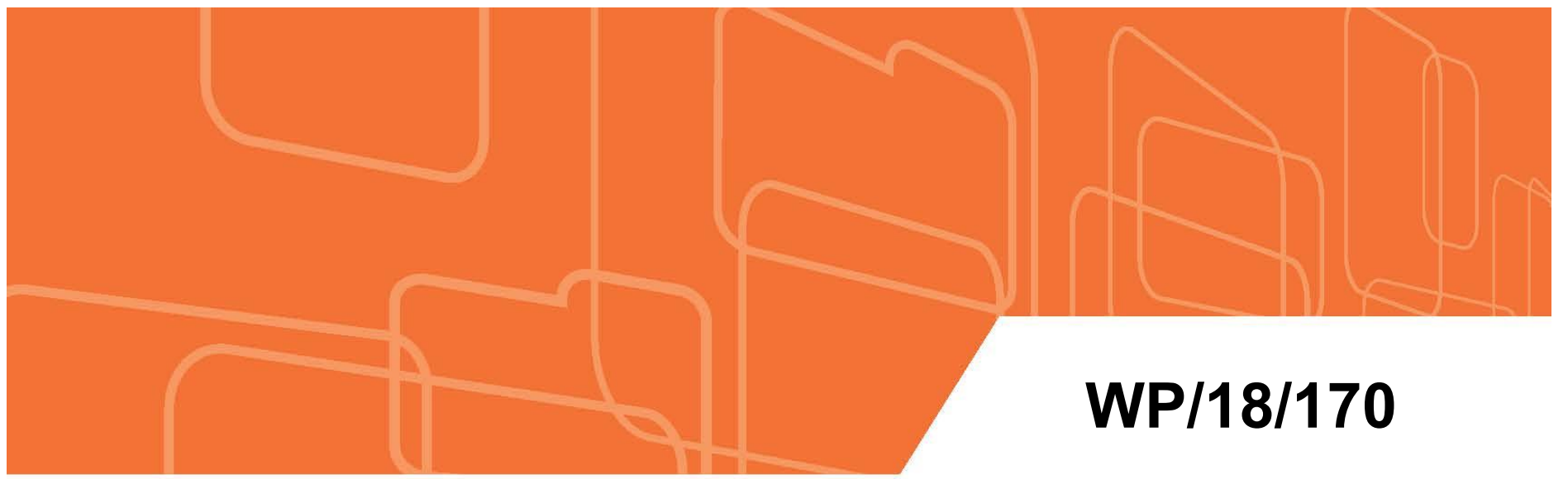

\section{IMF Working Paper}

\section{Twin Deficits in Developing Economies}

by Davide Furceri and Aleksandra Zdzienicka

IMF Working Papers describe research in progress by the author(s) and are published to elicit comments and to encourage debate. The views expressed in IMF Working Papers are those of the author(s) and do not necessarily represent the views of the IMF, its Executive Board, or IMF management. 


\title{
IMF Working Paper
}

Research and Fiscal Affairs Departments

Twin Deficits in Developing Economies

Prepared by Davide Furceri and Aleksandra Zdzienicka ${ }^{1}$

Authorized for distribution by Chris Papageorgiou and Era Dabla-Norris

July 2018

\section{IMF Working Papers describe research in progress by the author(s) and are published} to elicit comments and to encourage debate. The views expressed in IMF Working Papers are those of the author(s) and do not necessarily represent the views of the IMF, its Executive Board, or IMF management.

\begin{abstract}
This paper provides new evidence on the existence and magnitude of the "twin deficits" in developing economies. It finds that a one percent of GDP unanticipated increase in the government budget balance improves, on average, the current account balance by 0.8 percentage point of GDP. This effect is substantially larger than that obtained using standard measures of fiscal impulse, such as the cyclically-adjusted budget balance. The results point to heterogeneity across countries and over time. The effect tends to be larger: (i) during recessions; in countries (ii) that are more open to trade; (iii) that have less flexible exchange rate regimes; and (iv) with lower initial public debt-to-GDP ratios.
\end{abstract}

JEL Classification Numbers: E62, F32, F42

Keywords: Fiscal policy, Current account, Twin Deficits, Developing Economies.

Authors’ E-Mail Addresses: dfurceri@,imf.org, azdzienicka@imf.org

\footnotetext{
${ }^{1}$ We are grateful to participants of various IMF seminars for comments and suggestions. This working paper is part of a research project on macroeconomic policy in low-income countries supported by U.K.'s Department for International Development. We are also grateful to Tiffany Wrong for excellent research assistance, and Karina Chavez for excellent editorial assistance. The views expressed in this Working Paper are those of the author(s) and do not necessarily represent those of the IMF, IMF policy, or of DFID.
} 


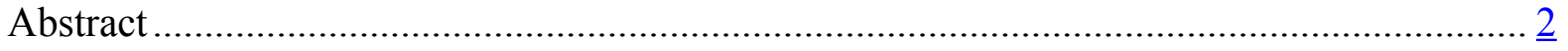

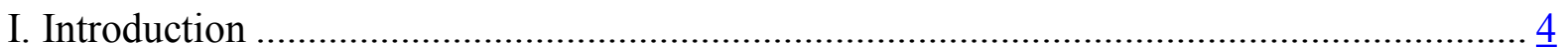

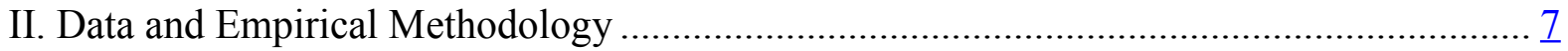

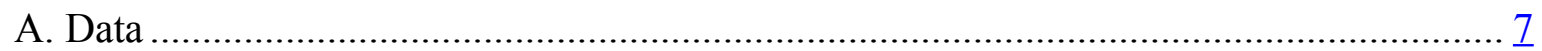

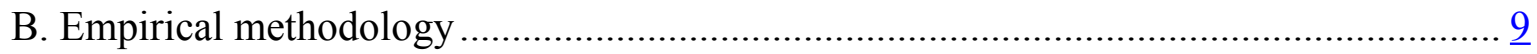

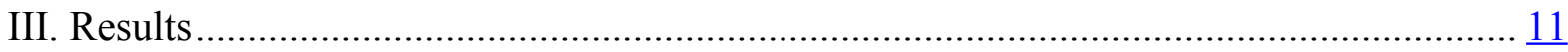

A. Baseline and robustness checks .......................................................................... 11

B. Comparing our results with the literature........................................................... 13

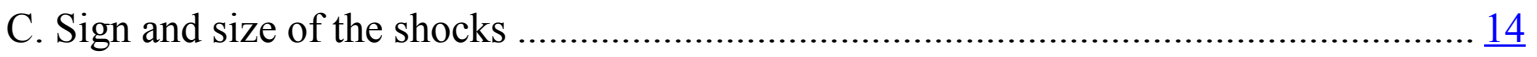

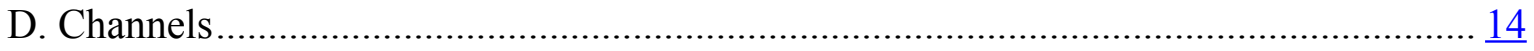

E. Role of policy, cyclical, and structural factors ....................................................... 15

IV. Conclusions and Policy Implications....................................................................... 20

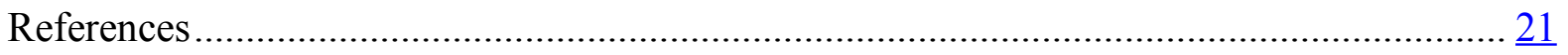

\section{Tables}

1. The effect of fiscal shocks on the Government Budget Balance ........................24

\section{Figures}

1. Impact of Fiscal Shocks on the Current Account ………..............................................

2. Impact of Fiscal Shocks on the Current Account: EMs vs. LICs....................................... 26

3. Impact of Fiscal Shocks on the Current Account - controlling for other variables .............. 27

4. Impact of Fiscal Shocks on the Current Account - robustness to shock measures ............. 28

5. Impact of Fiscal Shocks on the Current Account - comparison to the literature .................. 29

6. Impact of Fiscal Shocks on the Current Account: Sign of the Shock .................................. $\frac{30}{31}$

7. Impact of Fiscal Shocks on Investment and Saving ......................................................... $\frac{31}{32}$

8. Impact of CAB changes on Investment and Saving ......................................................... $\frac{32}{33}$

9. Impact of Fiscal Shocks on the Current Account Balance: recessions vs. expansions ........ $\underline{33}$

10. Impact of Fiscal Shocks on the Current Account Balance-Trade Openness ………......... 34

11. Impact of Fiscal Shocks on the Current Account Balance_Exchange Rate Regimes .... $\frac{35}{36}$

12. Impact of Fiscal Shocks on the Current Account Balance-Public Debt....................

\section{Appendices}

Table A1. Government Expenditure Shocks in EMDEs ...................................................... $\frac{37}{4}$

Table A2. Mean square error of government spending growth rate forecasts................

Figure A1. Distribution of Government Expenditure Shocks in EMDEs ………………….... 40

Figure A2. Impact of Fiscal Shocks on the Nominal Exchange Rate ………............................ 41 


\section{INTRODUCTION}

How strong is the relationship between fiscal and current account deficits in developing countries? Answering this question is relevant from both policy and academic perspectives. Policymakers would like to know to what extent fiscal adjustment contributes to addressing external disequilibria, especially in the context of increasing external and public-sector imbalances in many developing economies. From an academic point of view, this is important as, in contrast to advanced economies, much less is known about the magnitude of the twin deficits in developing economies. A key reason is the methodological challenge of identifying fiscal shocks that are uncorrelated with contemporaneous macroeconomic variations.

Previous studies on the effect of fiscal policy on the current account have relied on two main approaches to identify exogenous fiscal shocks. First, the "narrative approach" (e.g., Romer and Romer, 2010; Devries et al., 2011) analyzes official documents to identify fiscal policy actions that are motivated by budget considerations and not by macroeconomic conditions. Second, the Structural Vector Autoregression (SVAR) approach developed by Blanchard and Perotti (2002) relies on the assumption that given implementation lags in the budget process, government spending is unlikely to respond to macroeconomic shocks within a quarter. The former has been mainly applied to advanced economies (Bluedorn and Leigh, 2011; Feyrer and Shambaugh, 2012), while the latter to both advanced (Beetsma et al., 2007) and some emerging market economies (Abbas et al., 2011).

In contrast, previous studies for developing economies have typically relied on the cyclically-adjusted fiscal budget balance (CAB) — based on multiyear averages or filters to smooth business cycle fluctuations - to identify fiscal shocks. This approach, however, is subject to endogeneity issues, which are likely to bias the magnitude of the twin deficits toward 
zero. First, it might reflect reverse causality as fiscal actions captured by the CAB may occur as a response to growing external vulnerabilities. Second, there could be an omitted bias problem as fluctuations in output and commodity prices - positively (negatively) correlated with investment (the current account)—might still affect the CAB.

To address these issues, we follow Auerbach and Gorodnichenko (2013a, 2013b) and identify fiscal shocks as the forecast errors in government spending. There are three reasons to adopt this approach. First, the limited publicly available official documentation renders using a narrative approach to identify fiscal shocks for a large set of emerging and developing economies difficult. ${ }^{2}$ Second, data limitations (including lack of government spending data at the quarterly frequency) preclude the use of SVARs for many of these countries. ${ }^{3}$ Third, the approach adopted in the paper overcomes the problem of "fiscal foresight," which arises when agents react to anticipated rather than realized shocks. ${ }^{4}$

After identifying government spending shocks, we apply the local projections method (Jordà, 1995) to estimate the short- and medium-run responses of the current account to these shocks for a panel of 114 EMDEs over the period $1990-2015 .{ }^{5}$ To quantify the magnitude of

\footnotetext{
${ }^{2}$ Carrière-Swallow et al. (2018) extend previous studies using the narrative approach to identify fiscal shocks for 14 countries in Latin America and the Caribbean.

${ }^{3}$ Ilzetki et al. (2013) assembled quarterly data on government spending for 24 emerging market economies. In contrast, the methodology chosen in the paper allows us to cover an unbalanced sample of 114 EMDEs.

${ }^{4}$ See, for instance, Forni and Gambetti (2010), Leeper et al. (2012), Leeper et al. (2013), and Ben Zeev and Pappa, (2015). Agents receiving news about changes in government spending in advance may alter their consumption and investment decisions well before the changes occur. An econometrician who uses the information contained in the change in actual spending would be relying on a different information set than that used by economic agents, and this may lead to biased estimates. By using forecast errors, the econometrician's information is aligned to that of economic agents.

${ }^{5}$ The classification of countries in EMDEs and advanced economies (AEs) throughout the paper follows the one adopted by the IMF WEO.
} 
the twin deficits, we instrument the ratio of government budget balance to GDP with the identified fiscal shocks (Ramey and Zubairy, 2018). Next, we analyze some of the channels through which fiscal shocks affect the current account balance (saving, investment and exchange rate). In line with the literature on the heterogenous impact of the fiscal policy, we also test whether cyclical, structural, and policy conditions matters for the relationship between fiscal and current account deficits.

The paper's main results can be summarized as follows:

- One percent of GDP unanticipated increase in the budget balance on average improves the current account balance by 0.8 percentage point of GDP. This effect is robust controlling for all macroeconomics shocks embedded in growth news (i.e., forecast errors in output growth).

- In the short term, the current account adjustment in the response to fiscal consolidation mostly occurs through a contraction in investment.

- The magnitude of the twin deficits for emerging markets and developing economies is similar to that found for advanced economies using the narrative approach but substantially larger than that obtained for EMDEs using the $\mathrm{CAB}{ }^{6}$ The main reason is the different effect of these two shock measures on investment. An improvement in the CAB has a significantly smaller effect due to the omitted bias described above.

- The effect depends on the sign of the shocks and varies over time and across countries. In particular, the effect tends to be larger: (i) during recessions; (ii) in countries that are

\footnotetext{
${ }^{6}$ See, for instance, Abbas and others (2011) that find a magnitude of the twin deficits of about 0.1-0.2.
} 
more open to trade; (iii) that have less flexible exchange rate regimes; and (iv) with lower initial public debt-to-GDP ratios.

The rest of the paper is organized as follows. Section II discusses the data and empirical methodology. Section III presents the results. Section IV concludes summarizing the main findings and providing policy implications.

\section{DAta AND EMPIRICAL Methodology}

\section{A. Data}

\section{Fiscal shocks}

Following Auerbach and Gorodnichenko (2013a, 2013b), we identify unanticipated fiscal shocks as the forecast error in government spending. ${ }^{7}$ We use various vintages of the IMF World Economic Outlook (WEO) publications that have a large time and cross-sectional coverage of government expenditure forecasts for many EMDEs. In particular, we first compute the unpredictable innovation to government spending at time $t\left(F E_{t \mid t-1}\right)$, defined as the difference between the growth rate of actual government spending $\left(\Delta \ln G_{t}\right)$ and IMF forecast of the growth for time $t$ made at time $t-1\left(\Delta \ln G_{i, t \mid-1}\right)$ :

$F E_{i, t \mid t-1}=\Delta \ln G_{i, t}-\Delta \ln G_{i, t \mid-1}$

where $i$ and $t$ denote the cross-sectional and time dimension, respectively.

As demonstrated by An et al. (2018), WEO forecasts of fiscal variables are generally very accurate, especially when compared to those of the private sector. The most likely reason is the continuous information flow between the IMF and finance ministries of the various

\footnotetext{
${ }^{7}$ Consistent with Auerbach and Gorodnichenko (2013b) and the previous literature on fiscal multipliers, our government spending series is the sum of real public consumption expenditure and real government gross capital formation.
} 
member countries. Therefore, it is highly unlikely that forecast errors computed according to the methodology above might be dominated by what Ricco (2015) labels "misperceptions about fiscal changes." Also, using the forecast made in October of the same year further increases the chances that forecast errors capture unexpected policy changes rather than mere misperceptions. Finally, as discussed in the introduction, this methodology solves by construction the problem of "fiscal foresight."

We use forecasts of government expenditures made in October of the same year to minimize the likelihood that unanticipated changes in government spending arise due to the potentially endogenous response of fiscal policy to the state of the economy. ${ }^{8}$ In fact, even if shocks are unanticipated, they may still occur in response to business cycle conditions. For example, the government may be forced to cut spending because growth turns out to be unexpectedly weak. To affect our estimates, such adjustments, however, need to happen within the same quarter when news about the state of the economy is received (i.e., between October and December). ${ }^{9}$ This is highly unlikely given requirement imposed by parliaments and the legislative process (see also Blanchard and Perotti, 2002). Nevertheless, we show that our findings are robust even when controlling for unexpected changes in economic activity.

In a second step, we purge the forecast error of any predictable components by projecting it on lags of several macroeconomic variables (output, government spending, government revenue, real exchange rate, current account and inflation) and taking the residual of this projection as a shock.

\footnotetext{
${ }^{8}$ In the next section, we show that the results are robust to using the forecasts of government expenditures made in April of the same year.

${ }^{9}$ All fiscal and junctural information up to October of a given year is incorporated in the forecasts made in October.
} 
Figure A1 in the Appendix reports the distributions of government spending shocks for EMDEs. The average (median) of the shock is about $-0.1(0.1)$ percent, while the bulk of the shocks (between the $1^{\text {st }}$ and the $99^{\text {th }}$ percentile) lie between -99 and 100 percent. Table A1 in the Appendix reports descriptive statics for each country.

\section{Other data}

Data on current account, as well as for other controls used in the empirical specifications, are taken from IMF World Economic Outlook and International Financial Statistics database. Information on the exchange rate regime is taken from Ilzetzki et al. (2017). Our estimation sample covers an unbalanced panel of 114 developing countries over the period 1990-2015.

\section{B. Empirical methodology}

We estimate the average impact of anticipated government spending shocks on the current account balance using the local projection method (Jordà, 2005). This approach has been advocated by Stock and Watson (2007) and Auerbach and Gorodnichenko (2013b), among others, as a "flexible alternative" that does not impose the dynamic restrictions embedded in vector autoregressions (or autoregressive-distributed lag) specifications, and it is particularly suited to estimating nonlinearities in the dynamic responses. The baseline regression is the following:

$c a_{i, t+k}=\alpha_{i}^{k}+\vartheta_{t}^{k}+\beta^{k} \operatorname{Shock}_{i, t}+\theta^{k} X_{i, t}+\varepsilon_{i, t}^{k}$,

where $c a$ is the current account balance (or alternatively, total savings and investment) as share of GDP; $\alpha_{i}$ are country fixed effects, to control for all time-invariant differences across countries (such as countries' average growth rates); $\vartheta_{t}$ are time fixed effects, to control for 
global shocks such as shifts in oil prices or the global business cycle; Shock $k_{i, t}$ is the government spending shock discussed above; $X_{i t}$ is a set of control variables including two lags of the

shocks, as well as two lags of the current account; $\theta^{k}$ is a vector of coefficients; and $\varepsilon_{i, t}^{k}$ is the error term.

Equation (2) is estimated for each $k=0,1, \ldots 3$, where $k=0$ is the year when the shock takes place. Impulse-response functions are computed using the estimated coefficients $\beta^{k}$, while the associated confidence bands are obtained using the estimated standard errors of the coefficients $\beta^{k}$, based on clustered robust standard errors at the country level.

\section{Computing the magnitude of the twin deficits}

A traditional way to compute the magnitude of the twin deficits based on estimates from equation (2) would be to take the estimated response of unexpected expenditure growth shocks and use an ex-post conversion factor based on the sample average of the ratio of GDP to government expenditure. One problem with this approach, however, is that this ratio significantly changes over time and across countries. We follow Ramey and Zubairy (2018) and address this problem by instrumenting the changes in the ratio of the government budget balance to GDP with our identified fiscal policy shocks.

The results of the first-stage estimates are reported in Table 1. They suggest that a 100 percent unanticipated increase in government spending reduces, on average, the budget balance by about 2 percent of GDP. This effect is precisely estimated, with a F-statistic of 14.35 , above the Kleibergen-Paap rk Wald F statistic of weak exogeneity. 


\section{RESUlts}

This section discusses the baseline results and robustness checks, the channels (investment and savings) through which fiscal shocks affect the current account, as well as whether the effects depend on cyclical, structural, and policy factors.

\section{A. Baseline and robustness checks}

\section{Baseline}

The results based on equation (2) indicate that fiscal consolidation significantly affects the current account balance in developing countries. Figure 1 shows that 1 percentage point of GDP fiscal contraction improves the current account balance by about 0.8 percentage point of GDP a year after the shock, and is statistically significant up to two years after the shock. The impact appears larger-even though not statistically different from the baseline results — for emerging market countries, where a fiscal shock increases the current account balance by about 1.1 percentage points after a year (Figure 2).

\section{Robustness checks}

\section{Additional controls}

One possible concern with the identification of government spending shocks is that they may be endogenous to output growth surprises. While the use of forecasts made in October of the same year mitigates this concern, we check the robustness of our results by adding current and lagged output growth innovations — defined as the difference between actual GDP 
growth and the rate forecasted by analysts in October of the same year-as controls. ${ }^{10}$ The results presented in Figure 3 (Panel A) are very similar and not statistically different from the baseline.

Further, we check whether the effects of government spending shocks on the current account are robust to the inclusion of other factors affecting the current account in the shortterm. In particular, we consider as controls: (i) changes in the terms of trade; and (ii) financial crises. ${ }^{11}$ The results in this case are also very similar to those obtained in the baseline, further validating that the fiscal policy shocks identified in the analysis can be deemed as exogenous (Figure 3, Panel B).

\section{Shocks}

While the use of the forecasts of government expenditures made in October of the same year minimizes the likelihood that unanticipated changes in government spending arise due to the potentially endogenous response of fiscal policy to the state of the economy, one drawback is that the forecast error is only capturing surprises (or unanticipated government spending) between October and December. To check whether the results hold based on forecast made earlier in the year, we repeat the analysis using the IMF forecasts made in April of the same year. The results obtained with this approach are very similar and not statistically different from those obtained in the baseline (Figure 4, Panel A). ${ }^{12}$

\footnotetext{
${ }^{10}$ In practice, we adopt a two-stage approach. First, we regress government spending forecast errors on GDP growth forecast errors and then use the residuals from this regression as our measure of government spending shocks.

${ }^{11}$ The source of the data for these variables are IMF WEO and Laeven and Valencia (2012), respectively.

12 The results of the first-stage estimates suggest that a 100 percent unanticipated increase in government spending reduces, on average, the budget balance by about 2.5 percent of GDP. This effect is precisely estimated, with a F-statistic of 19.15 .
} 
Another issue concerning the identification of fiscal shocks is the quality of the forecast for developing countries. To examine whether this is the case, we compare the mean square error of government spending growth forecasts computed for EMDEs with similarconstructed forecast errors for AEs. The results presented in Table A2 of the Appendix confirm that the mean square is larger in EMDEs than in AEs. An important issue is therefore whether our results are driven by very large mean square errors. To check this, we replicate the analysis by dropping from the estimation sample observations with mean square errors above the $5^{\text {th }}$ percentile of the distribution of mean square errors. The results presented in Figure 4 (Panel B) also in this case are similar and not statistically different from those obtained using the full sample.

\section{B. Comparing our results with the literature}

To compare our results with the previous findings in the literature for advanced and developing economies, we perform two empirical exercises. First, we estimate equation (2) only for advanced economies. The magnitude of the twin deficits that we find for these countries (about 0.8 at peak, Figure 5 Panel A) is very close to that obtained using the narrative approach (Bluedorn and Leigh, 2011) and to that obtained for EMDEs.

Second, we re-estimate equation (2) for developing economies using changes in the $\mathrm{CAB}$ as a measure of the fiscal shocks. The results of this exercise suggest that a percentage point increase in the $\mathrm{CAB}$ improves the current account by 0.25 percentage point of GDP a year after the shock, with the effects becoming statistically insignificant afterward (Figure 5, 
Panel B). The magnitude of the effect is consistent with previous findings in the literature using the $\mathrm{CAB}$ (e.g., Abbas et al., 2011), but significantly smaller than the one obtained in the baseline, most likely because of the endogenous nature of the CAB. We discuss this issue further in the next sub-section D examining the impact of fiscal shocks on savings and investment.

\section{Sign and size of the shocks}

An interesting question is whether the average response of the current account to fiscal shocks differs across fiscal expansions and consolidations. To answer this question, we estimate the following equation, where $D$ is a dummy variable that takes value one for positive shocks (expansions) and zero (consolidations) otherwise:

$c a_{i, t+k}=\alpha_{i}^{k}+\vartheta_{t}^{k}+\beta_{1}^{k} D_{i t} \operatorname{Shock}_{i, t}+\beta_{2}^{k}\left(1-D_{i t}\right) \operatorname{Shock}_{i, t}+\theta^{k} X_{i, t}+\varepsilon_{i, t}^{k}$,

The results (Figure 6) suggest that the response to fiscal consolidation is not statistically different from the response to fiscal expansion.

\section{Channels}

To better understand the channels through which fiscal policy affects the current account in EMDEs, we analyze the impact of fiscal shocks on total saving and investment. In particular, we estimate equation (2) by replacing the current account balance with investment and saving (both as a share of GDP). The results in Figure 7 show that the adjustment in the current account balance following fiscal consolidation mostly occurs through a persistent reduction of investment, rather than through a significant increase in saving. An unanticipated improvement in the fiscal balance of 1 percentage point of GDP lowers domestic investment by 0.8 percentage point of GDP a year after the shock and 1.6 
percentage point of GDP at the peak (Figure 8.1, Panel A). In contrast, the impact of a fiscal shock on saving is positive but significant only two years after the shock (Panel B).

The results are in line with those found using the narrative approach for advanced economies (Bluedorn and Leigh, 2011), but differ from the results obtained using changes in the $\mathrm{CAB}$. In particular, the response of investment to changes in the $\mathrm{CAB}$ is significantly smaller than that obtained using exogenous fiscal shocks (Figure 8, Panel B). As previously discussed, this reflects the fact that the $\mathrm{CAB}$ is not entirely purged for fluctuations in output and commodity prices, which may be positively correlated with investment.

\section{E. Role of policy, cyclical, and structural factors}

\section{State of the economy: the role of the business cycle}

Several studies in the literature have shown that the response of output to government spending shocks tends to be higher during periods of recessions than in expansions (see, among others, Auerbach and Gorodnichenko 2013a, 2013b; and Blanchard and Leigh 2013). Therefore, an interesting question is whether the responses of the current account to fiscal shocks vary across states of the business cycle. This question is also policy-relevant at the current juncture, given that several EMDEs are adopting fiscal consolidation measures in a period of weak economic activity.

To analyze whether economic conditions affect the impact of the fiscal shocks on the current account, we extend equation (2) as follows:

$$
\begin{aligned}
& c a_{i, t+k}=\alpha_{i}^{k}+\vartheta_{t}^{k}+G\left(z_{i t}\right)\left[\beta_{L}^{k} \operatorname{Shock}_{i, t}+\theta_{L}^{k} X_{i, t}\right]+\left(1-G\left(z_{i t}\right)\right)\left[\beta_{H}^{k} \operatorname{Shock}_{i, t}+\theta_{H}^{k} X_{i, t}\right]+ \\
& +\varepsilon_{i, t}^{k}
\end{aligned}
$$


where $G\left(z_{i t}\right)$ is a smoothing transition function of $z$-which is GDP growth, normalized to have a zero mean and unit variance. ${ }^{13}$ This transition function can be interpreted as the probability of the economy being in a recession. $G\left(z_{i t}\right)=1$ corresponds to a situation in which the economy is in a deep recession, while $G\left(z_{i t}\right)=0$ corresponds to the economy being in a strong expansion.

This approach is equivalent to the smooth transition autoregressive model developed by Granger and Terävistra (1993). The advantage of this approach is twofold. First, compared with a model in which each dependent variable would interact with a given variable (e.g., growth), it permits to test directly whether the effect of fiscal shocks varies across different regimes (e.g., recessions and expansions). Second, compared with SVARs estimated for each regime it allows the effect of fiscal shocks to change smoothly between regimes by considering a continuum of states to compute the impulse response functions, thus making the response more stable and precise.

The results presented in Figure 9 (Panel A and B) show that fiscal shocks tend to have a larger and more persistent on the current account balance when they occur in recessions. In contrast, the effect is not statistically significant in periods of high growth after one year. This is due to a larger response of investment in periods of weak growth and is consistent

\footnotetext{
${ }^{13}$ Ideally one would like to consider a measure of output gap. Unfortunately, measures of potential output are not available for many countries, and there are a number of issues (structural breaks, optimal smoothness parameters varying across countries) when applying filtering techniques to GDP series in many developing economies. Following Auerbach and Gorodnichenko (2013b), we set $G\left(z_{i t}\right)=\frac{\exp \left(-\gamma z_{i t}\right)}{1+\exp \left(-\gamma z_{i t}\right)}, \quad \gamma=1.5$ The results are robust to different values of $\gamma$, as well as considering lagged GDP growth instead of current one.
} 
with the evidence of previous studies on larger fiscal multipliers in recessions (e.g., Auerbach and Gorodnichenko 2013a, 2013b; Blanchard and Leigh 2013; Owyang et al. 2013).

\section{Trade openness}

Trade openness is a potential source of heterogeneity in the response of the current account to fiscal shocks. On the one hand, the effect of fiscal shocks in more open economies on the current account could be smaller since a greater share of the additional demand stemming from a fiscal expansion would be "leaked out" through higher imports. On the other hand, as discussed by Corsetti and Muller (2006), in economies where the import content of both consumption and investment is high, domestic interest rates are not affected much by fiscal expansion, while an appreciation of the terms of trade substantially increases the real return to investment. As a result, the effect of fiscal shocks on the current account is larger through the investment channel.

To analyze whether the degree of trade openness (defined as the ratio of exports and import in GDP) affects the impact of the fiscal shocks on the current account, we extend equation (2) as follows:

$c a_{i, t+k}=\alpha_{i}^{k}+\vartheta_{t}^{k}+D_{i, t}\left[\beta_{L}^{k}\right.$ Shock $\left._{i, t}+\theta_{L}^{k} X_{i, t}\right]+\left(1-D_{i, t}\right)\left[\beta_{H}^{k} \operatorname{Shock}_{i, t}+\theta_{H}^{k} X_{i, t}\right]+$ $+\varepsilon_{i, t}^{k} \quad(4)$,

where $D$ is a dummy variable that takes value 1 for county-periods in which trade openness is above the average value in the sample (about 70 percent of GDP), and 0 otherwise. ${ }^{14}$ The

\footnotetext{
${ }^{14}$ Similar results are obtained using the median instead of the average as a threshold.
} 
results obtained using equation (4) suggest that the effect of fiscal shocks on the current account tends to be larger the higher is trade openness (Figure 10). However, given the relatively large standard errors, the difference in the current account responses is not statistically significant.

\section{Exchange rate}

According to the relative price channel, another potential source of heterogeneity in the response of the current account to fiscal shocks is the exchange rate regime. Under a flexible exchange rate regime, fiscal consolidation reduces the demand for home goods and money, inducing a nominal and real depreciation that improves net exports.

To test this hypothesis, we re-estimate equation (4) using as a dummy variable $D$, which take value 1 for countries-periods associated with a fixed exchange rate regime, and zero otherwise. ${ }^{15}$ The results presented in Figure 11 (Panel A and B) indicate that the impact of a fiscal shock on the current account balance is significantly larger and more persistent in countries with less flexible exchange rate arrangements. In contrast, the effect of fiscal shocks on the current account is not statistically significantly different from zero in countries with more flexible exchange rate regimes. This finding is consistent with previous evidence of Beetsma and others (2008) and Bluedorn and Leigh (2011) for advanced economies. ${ }^{16}$

\footnotetext{
15 The exchange rate regimes are identified using the coarse classification of Ilzetki et al. (2017). In particular, we classify fixed exchange rate regimes those with a score of 1 (No separate legal tender, Pre- announced peg or currency board arrangement, De facto peg) and 2 (De facto crawling band that is narrower than or equal to $+/-2 \%)$.

${ }^{16}$ Bluedorn and Leigh (2011) find the twin deficits hypothesis still holds in the euro zone countries, but the impact is lower than before the euro adoption.
} 
The evidence presented above suggest that the nominal exchange rate is a key mechanism underlying the twin deficits link. To further corroborate this evidence, we estimate the response of the nominal exchange rate to fiscal shocks using equation (2). The results suggest that 1 percent of GDP fiscal consolidation is associated with a deprecation of about 0.7 percent in the year of the shock, and of about 1 percent in the medium term (Figure A2 in the Appendix).

\section{Public debt}

Debt sustainability concerns might affect the effectiveness of fiscal policy. Economic agents may question the credibility of the fiscal actions in a high-debt environment and not respond to policy changes. Risk premiums also become important with forward-looking agents concerned about intertemporal solvency. Both arguments suggest that the effect of a fiscal shock on the current account may be weaker in countries with higher public debt (e.g., Nickel and Tudyka, 2014).

To empirically examine this issue, we estimate equation (4) where $D$ is a dummy variable that takes value 1 for county-periods in which the public debt-to-GDP ratio is above the average value in the sample (about 45 percent of GDP), and 0 otherwise. ${ }^{17}$ The results in Figure 12 indicate that the impact of fiscal shock is smaller in periods of higher public debt. ${ }^{18}$ This is due to a larger response of investment in periods of lower debt and is consistent with the evidence of previous studies on larger fiscal multipliers when the debt-to-GDP ratio is

\footnotetext{
${ }^{17}$ Similar results are obtained using the median instead of the average as a threshold.

18 The selection of these thresholds is based on Furceri and Zdzienicka (2012), who find that an increase in debt lowers output when the debt-to-GDP ratio exceeds 75 percent. Similarly, results are obtained estimating equation (3) using the debt-to-GDP ratio as interacting variable $\mathrm{z}$.
} 
low (Nickel and Tudyka, 2014). At the same time, the differences in the point estimates are small relative to the estimated standard errors and are in most of the cases not statistically significant.

\section{Conclusions ANd Policy IMPlications}

We provide new evidence of the existence of the "twin deficits" in developing economies. Using unanticipated government spending shocks for an unbalanced panel of 114 developing economies from 1990 to 2015, we find that a one percent of GDP unanticipated improvement in the government budget balance improves, on average, the current account balance by 0.8 percentage point of GDP. This effect is substantially larger than usually found in the literature using standard measures of fiscal policy changes such as the CAB. This finding has important policy implications as for a given target of external adjustment less fiscal consolidation is required than normally assumed.

Beyond this average effect lies some heterogeneity, both across states of the business cycle and across countries. The effect tends to be larger: (i) during recessions; (ii) in countries that are more open to trade; (iii) that have less flexible exchange rate regimes; and (iv) with lower initial public debt-to-GDP ratios. This heterogeneity has far-reaching implications for policymakers in deciding the magnitude of the fiscal adjustment needed to address external imbalances. 


\section{REFERENCES}

Abbas, S. M. A., J. Bouhga-Hagbe, A. Fatás, P. Mauro, R. C Velloso, 2011. "Fiscal Policy and the Current Account," IMF Economic Review, no. 59/4, pp. 603-629.

Abiad, A., D. Furceri and P. Topalova, 2015. "The Macroeconomic Effects of Public Investment: Evidence from Advanced Economies," IMF Working Papers, no. 15/95.

An, Zidong., Joao Tovar Jalles, Prakash Loungani, and Ricardo Sousa. "Do IMF Fiscal Forecasts add Value?", Journal of Forecasting, 2018, forthcoming.

Auerbach, A. J. and Y. Gorodnichenko, 2013a. "Output Spillovers from Fiscal Policy," American Economic Review, vol. 103, no. 3, pp. 141-146.

Auerbach, A. J. and Y. Gorodnichenko, 2013b. "Fiscal Multipliers in Recession and Expansion," in Alberto Alesina and Francesco Giavazzi (editors), Fiscal Policy after the Financial Crisis, National Bureau of Economic Research Conference Report, Chicago IL, University of Chicago Press, pp. 63-98.

Beetsma, R., M. Giuliodori, and F. Klaassen, 2007, "The Effects of Public Spending Shocks on Trade Balances and Budget Deficits in the European Union," Journal of the European Economic Association, vol. 6 /2-3, pp. 414-423, 2008.

Ben Zeev, Nadav and Evi Pappa. "Multipliers of unexpected increases in defense spending: An empirical investigation," Journal of Economic Dynamics and Control, vol. 57(C), 2015, pages 205-226.

Blanchard, Olivier, and Roberto Perotti. "An Empirical Characterization of the Dynamic Effects of Changes in Government Spending and Taxes on Output," The Quarterly Journal of Economics, vol. 117, no. 4, 2002, pp. 1329-1368.

Blanchard, O. and D. Leigh, 2013. "Growth Forecast Errors and Fiscal Multipliers," IMF Working Paper, no. 13/1 (Washington: International Monetary Fund).

Bluedorn, J. C., and D. Leigh, 2011. "Revisiting the Twin Deficits Hypothesis: The Effect of Fiscal Consolidation on the Current Account," IMF Economic Review, no. 59/4, pp. $582-602$. 
Carrière-Swallow, Y., A. David, and D. Leigh. Forthcoming. "The Effects of Fiscal Consolidations in Developing Economies: Evidence from Latin America," IMF Working Paper.

Corsetti, G. and G. J. Müller, 2006. "Twin deficits: squaring theory, evidence and common sense, “Economic Policy, vol. 21(48), pp. 597-638, October.

Devries, Pete and Guajardo, Jaime and Leigh, Daniel and Andrea Pescatori, 2011. "A New Action-Based Dataset of Fiscal Consolidation". IMF Working Papers, Vol. , pp. 190, 2011.

Feyrer, J. and J. Shambaugh, 2012. "Global Saving and Global Investment: The Transmission of Identified Fiscal Shocks," American Economic Journal: Economic Policy, vol. 4/2, pp .95-114.

Forni, M., and L. Gambetti, 2010. "Fiscal Foresight and the Effects of Government Spending," CEPR Discussion Paper.

Furceri, D. and A. Zdzienicka, 2012. "How Costly are Debt Crisis?" Journal of International Money and Finance, vol. 31/4, pp. 726-742.

Ilzetzki, Ethan, Enrique G Mendoza and Carlos A Vegh. "How Big (Small?) are Fiscal Multipliers?," Journal of Monetary Economics, vol. 60, no. 2, 2013, pp. 239-254.

Ilzetzki, Ethan, Carmen M. Reinhart, Kenneth S. Rogoff. "Exchange Arrangements Entering the 21st Century: Which Anchor Will Hold?," NBER Working Paper, 23134.

Jordà, Ò., 2005. "Estimation and Inference of Impulse Responses by Local Projections," American Economic Review, vol. 95, no. 1, pp. 161-182.

Lane, Philip R. and Gian Maria Milesi-Ferretti. "The External Wealth of Nations II: Revised and Extended Estimates of Foreign Assets and Liabilities, 1970-2004," Journal of International Economics, vol. 73, 2007, pp. 223-250

Leeper, Eric M, Alexander W Richter and Todd B. Walker. "Corrigendum: Quantitative Effects of Fiscal Foresight," American Economic Journal: Economic Policy, vol. 4, no. 3, 2012, pp. 283-283.

Leeper, Eric M, Todd B Walker and Shu-Chun S Yang. "Fiscal Foresight and Information Flows," Econometrica, vol. 81, no. 3, 2013, pp. 1115-1145. 
Nickel, C. and A. Tudyka, 2014. "Fiscal Stimulus in Times of High Debt: Reconsidering Multipliers and Twin Deficits," Journal of Money, Credit and Banking, vol. 46/7, pp. $1313-1344$.

Owyang Michael T, Valerie A Ramey and Sarah Zubairy, 2013. "Are Government Spending Multipliers Greater during Periods of Slack? Evidence from Twentieth-Century Historical Data," American Economic Review, vol. 103, no. 3, 2013, pp. 129-134.

Ramey, Valerie, A, and Sarah Zubairy. "Government Spending Multipliers in Good Times and in Bad: Evidence from U.S. Historical Data," Journal of Political Economy, 2018, forthcoming.

Ricco, G. "A New Identification of Fiscal Shocks Based on the Information Flow," $E C B$ Working Paper 1813, European Central Bank, 2015.

Romer, Christina D., and David H. Romer 2010. "The macroeconomic effects of tax changes: estimates based on a new measure of fiscal shocks." American Economic Review 100.3: 763-801.

Stock, J.H. and M.W. Watson, 2007. "Why Has U.S. Inflation Become Harder to Forecast?" Journal of Money, Credit and Banking, vol. 39/1, pp. 3-33, February. 
Table 1. The effect of fiscal shocks on the Government Budget Balance (percentage points of GDP)

\begin{tabular}{lc}
\hline Shock & $-1.917 * * *$ \\
& $(-3.79)$ \\
Shock & 0.395 \\
& $(1.09)$ \\
Shock & \\
& -0.040 \\
Current account & $(-0.14)$ \\
& $-0.053^{*}-1$ \\
Current account & $(-2.49)$ \\
& -0.022 \\
$\mathrm{~N}$ & $(-0.78)$ \\
$\mathrm{R}^{2}$ & 1,942 \\
Note: estimates based on Equation $(2)$ using the government budget balance as the dependent variable. Country- \\
and year-fixed effects are included but not reported. T-statistics based on robust clustered standard errors in \\
parentheses. ${ }^{* * * * * *}$ denote significance at 1 and 5 percent, respectively.
\end{tabular}


Figure 1. Impact of Fiscal Shocks on the Current Account (percentage points of GDP)

2

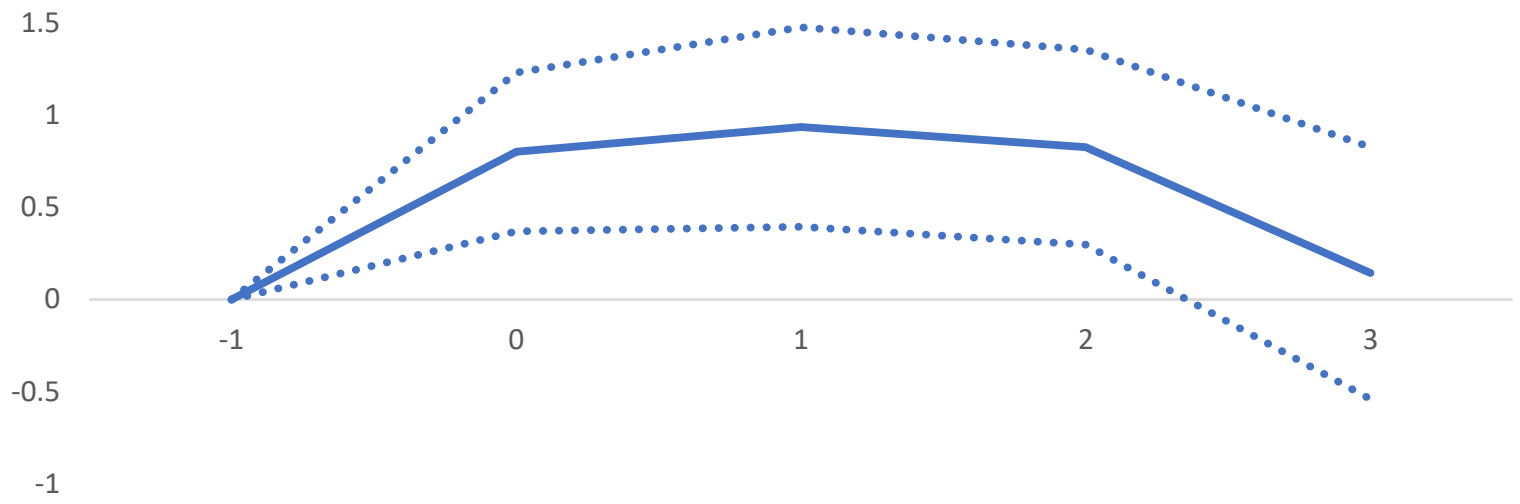

Note: $\mathrm{X}$-axis indicate years after the shock at $\mathrm{t}=0$. Blue lines denote the response of current account to 1 percentage point of GDP exogenous increase in the fiscal balance. Dotted lines 90 percent confidence bands. Estimates based on Equation (2). 
Figure 2. Impact of Fiscal Shocks on the Current Account: EMs vs. LICs (percentage points of GDP)

Panel A. Emerging Markets

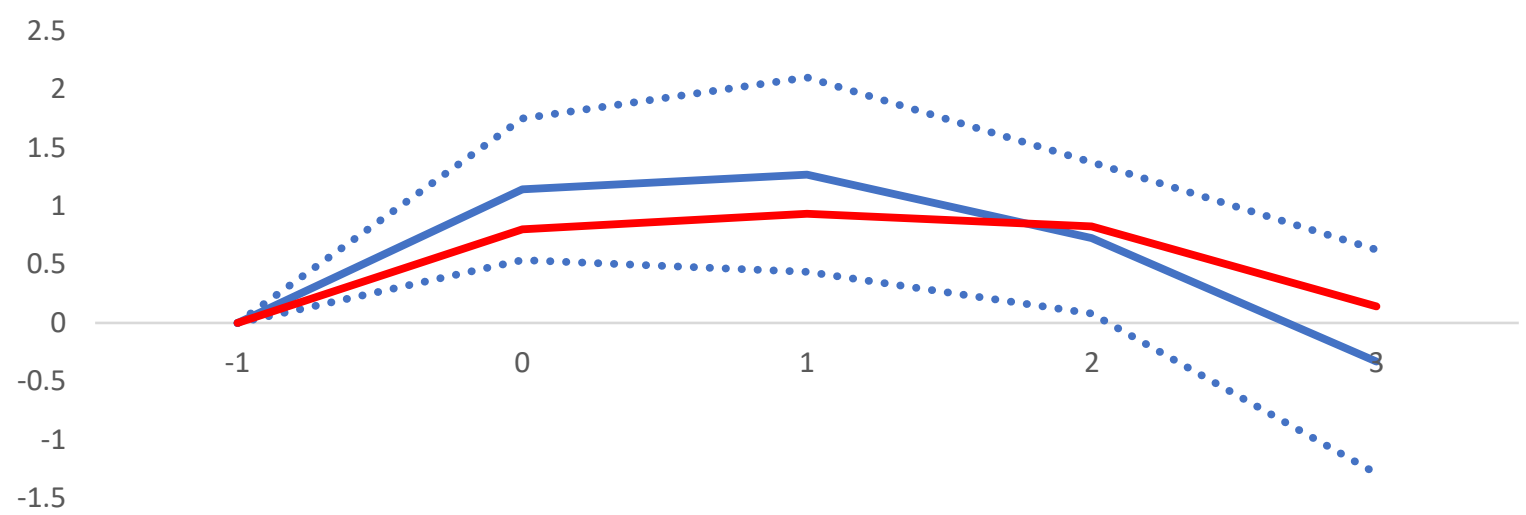

Panel B. Low-income Countries

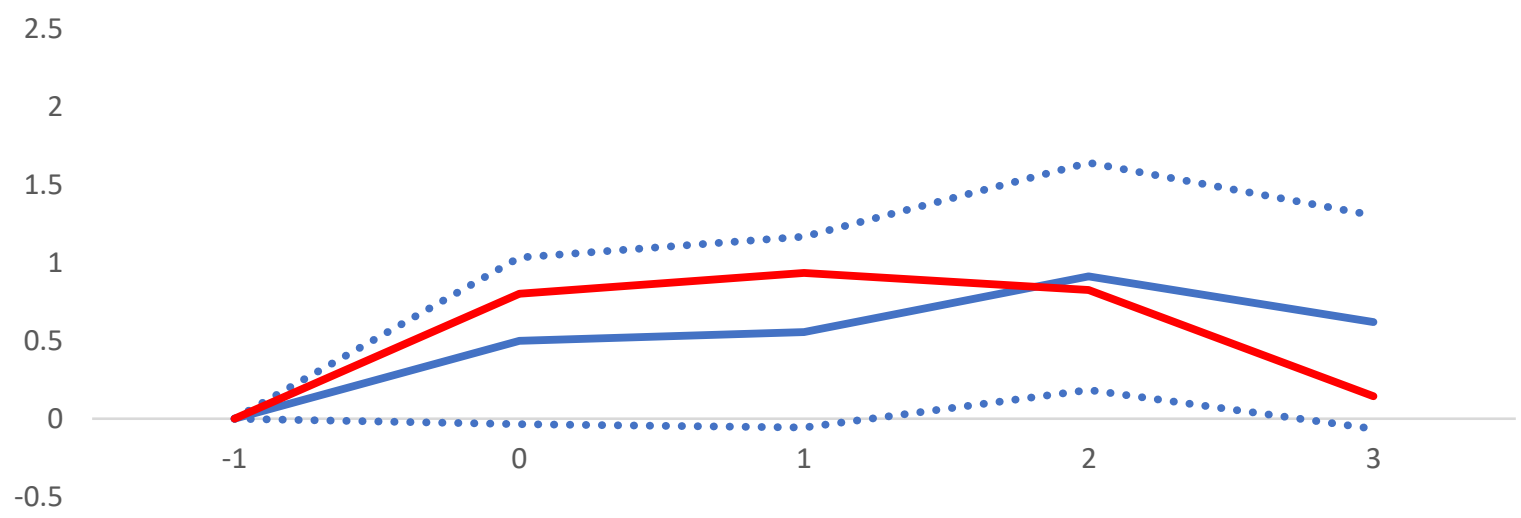

Note: $\mathrm{X}$-axis indicate years after the shock at $\mathrm{t}=0$. Blue lines denote the response of the current account to 1 percentage point of GDP exogenous increase in the fiscal balance. Dotted lines 90 percent confidence bands. Estimates based on Equation (2). Red lines indicate the baseline response in Figure 1. 
Figure 3. Impact of Fiscal Shocks on the Current Account - controlling for other variables (percentage points of GDP)

Panel A. Controlling for growth news

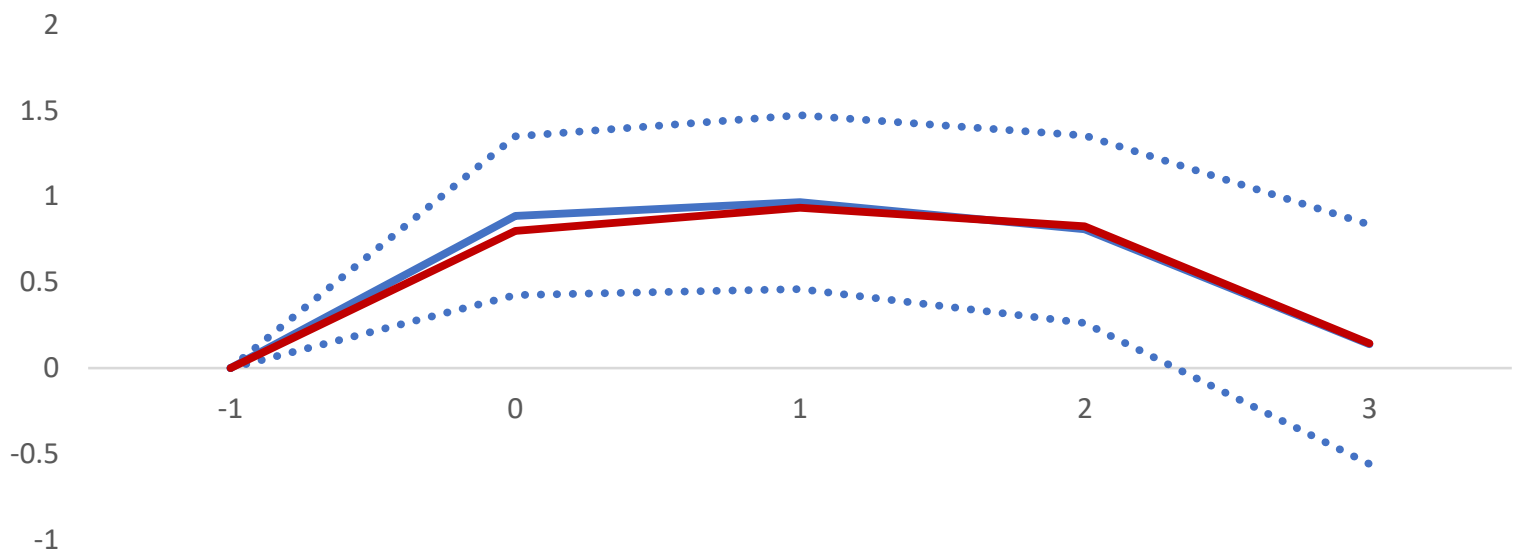

Panel B. Controlling for crisis and changes in terms of trade

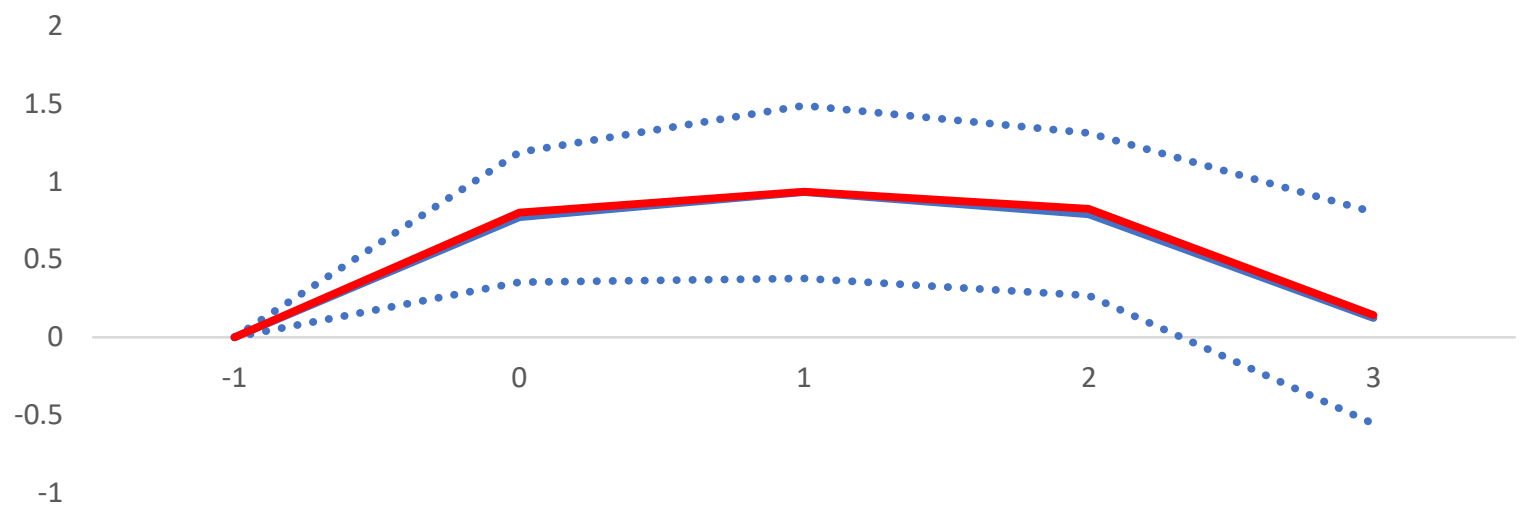

Note: $\mathrm{X}$-axis indicate years after the shock at $\mathrm{t}=0$. Blue lines denote the response of current account to 1 percentage point of GDP exogenous increase in the fiscal balance. Dotted lines 90 percent confidence bands. Estimates based on Equation (2). Red lines indicate the baseline response in Figure 1. 
Figure 4. Impact of Fiscal Shocks on the Current Account - robustness to shock measures (percentage point of GDP)

Panel A. Shocks based on forecasts made in April of the same year

2

1.5

1

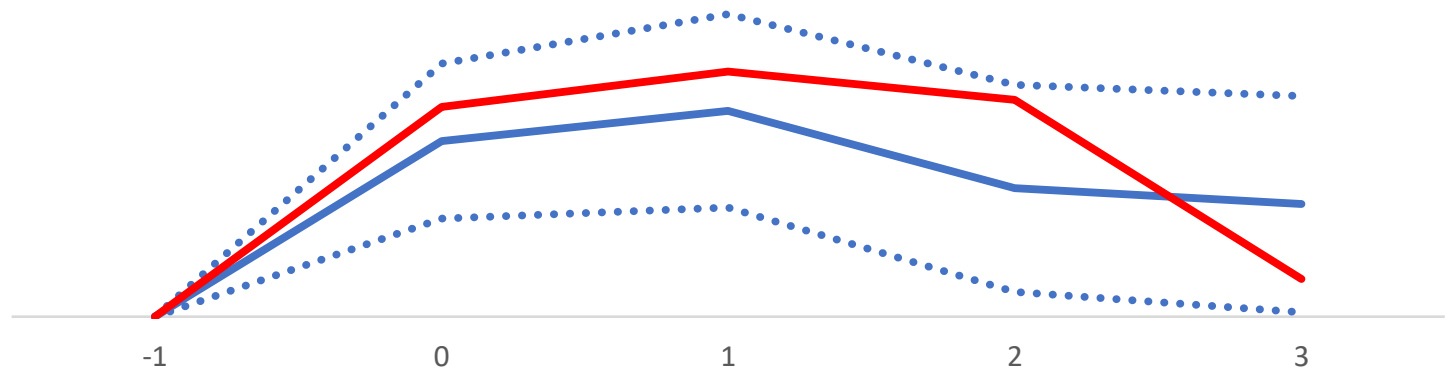

Panel B. Excluding large forecast errors

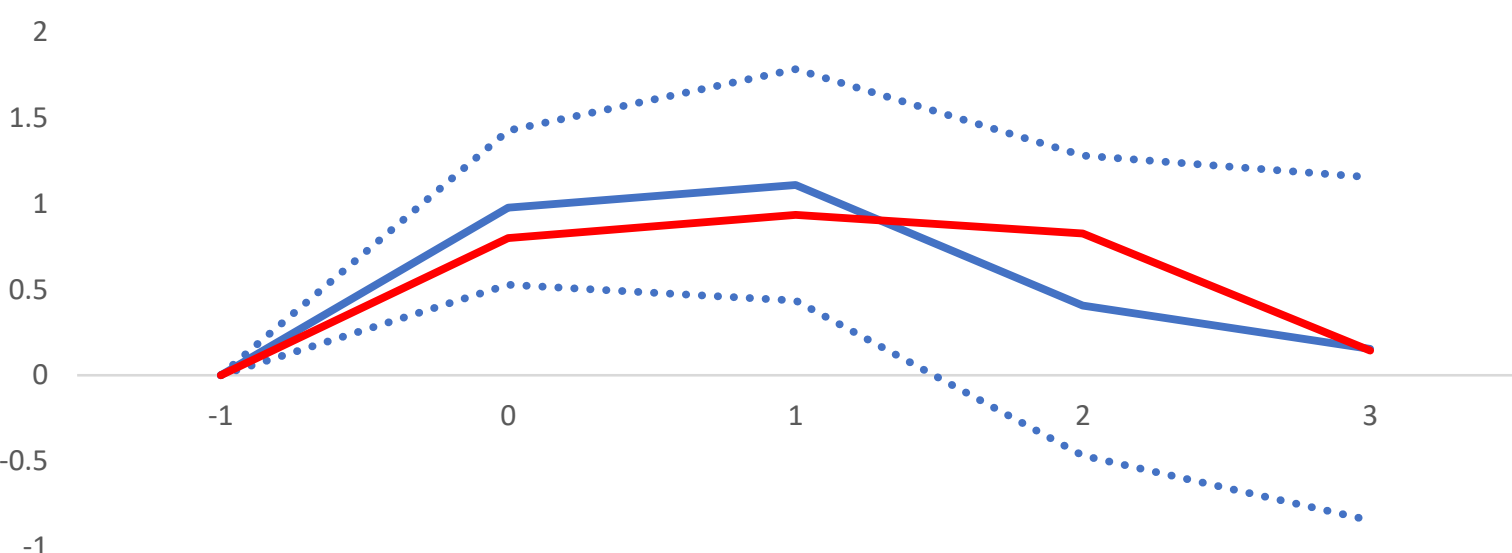

Note: $\mathrm{X}$-axis indicate years after the shock at $\mathrm{t}=0$. Blue lines denote the response of current account to 1 percentage point of GDP exogenous increase in the fiscal balance. Dotted lines 90 percent confidence bands. Estimates based on Equation (2). Red lines indicate the baseline response in Figure 1. Large forecast errors are defined as those with mean square errors above the $5^{\text {th }}$ percentile of the distribution. 
Figure 5. Impact of Fiscal Shocks on the Current Account - comparison to the literature (percentage point of GDP)

Panel A. Advanced Economies

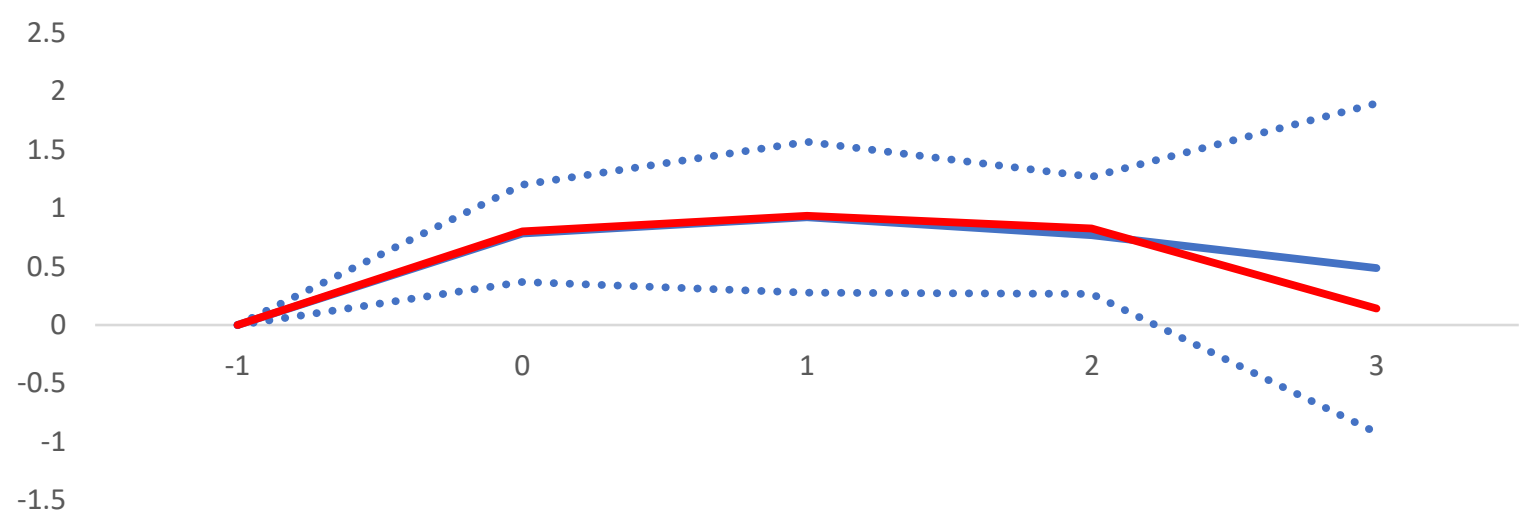

Panel B. Developing Economies: CAB versus Unanticipated Fiscal Shocks

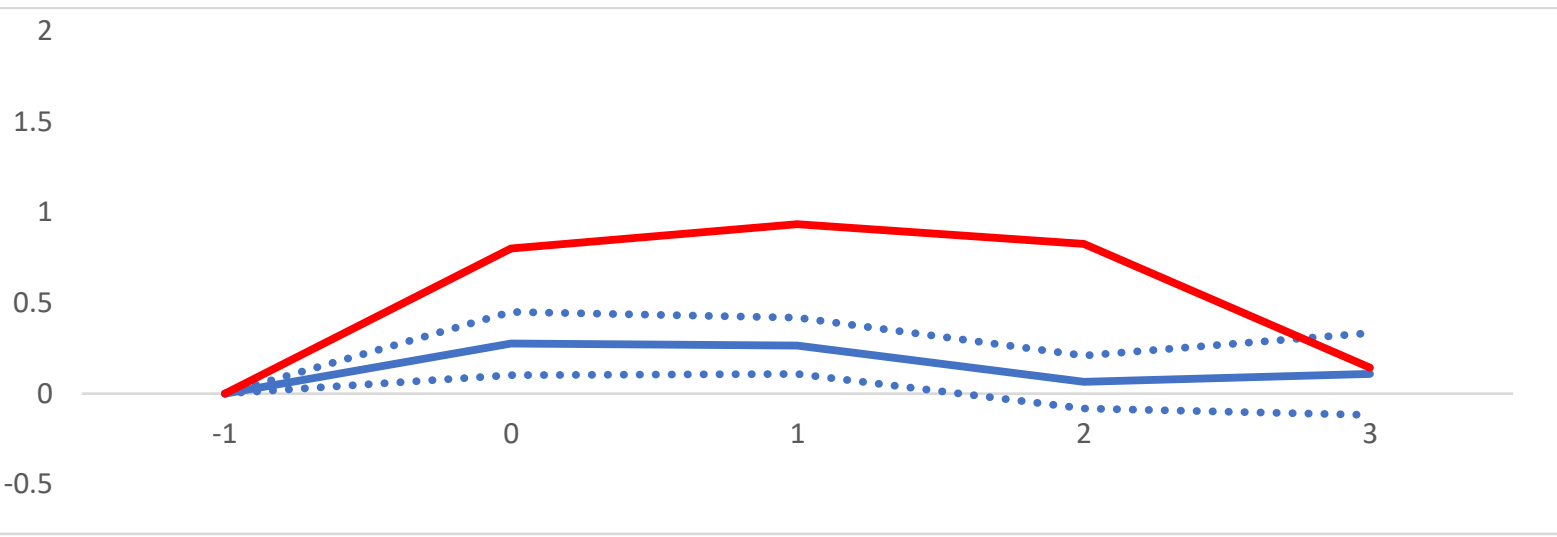

Note: $\mathrm{X}$-axis indicate years after the shock at $\mathrm{t}=0$. In Panel $\mathrm{A}$, blue lines denote the response of current account to 1 percentage point of GDP exogenous increase in the fiscal balance in AEs. In Panel B, blue lines denote the response of current account to 1 percentage point of GDP increase in the cyclically-adjusted fiscal balance. Dotted lines 90 percent confidence bands. Estimates based on Equation (2). Red lines indicate the baseline response in Figure 1. 
Figure 6. Impact of Fiscal Shocks on the Current Account: Sign of the Shock (percentage point of GDP)

Panel A: Expansionary Shocks

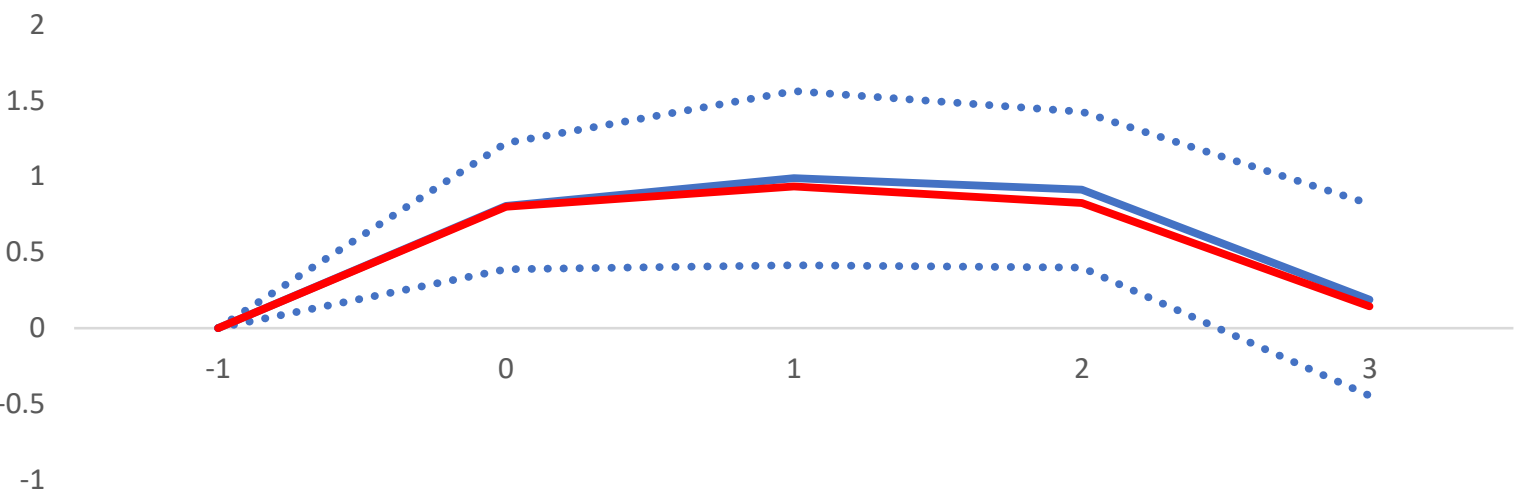

Panel B: Contractionary Shocks

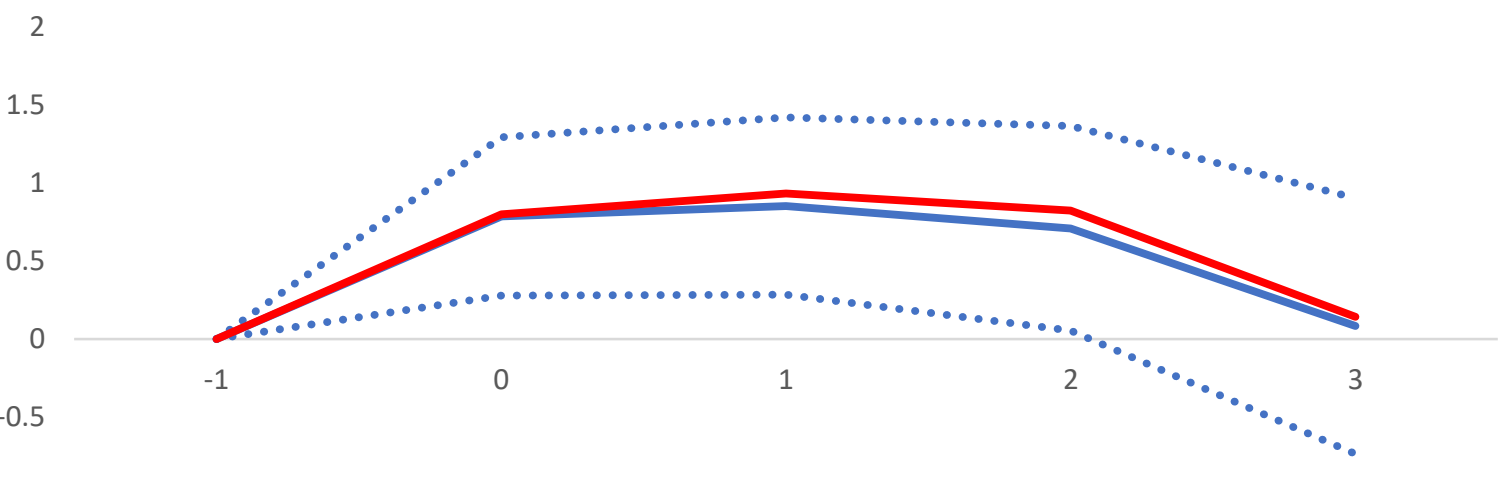

$-1$

Note: $\mathrm{X}$-axis indicate years after the shock at $\mathrm{t}=0$. Blue lines denote the response of current account to 1 percentage point of GDP exogenous increase in the fiscal balance. Dotted lines 90 percent confidence bands. Expansionary (contractionary) shocks are fiscal shocks with an unanticipated change in government expenditure in percent of GDP below (above) zero. The results are based on Equation (3). Red lines indicate the baseline response in Figure 1. 
Figure 7. Impact of Fiscal Shocks on Investment and Saving (percentage point of GDP)

Panel A. Investment

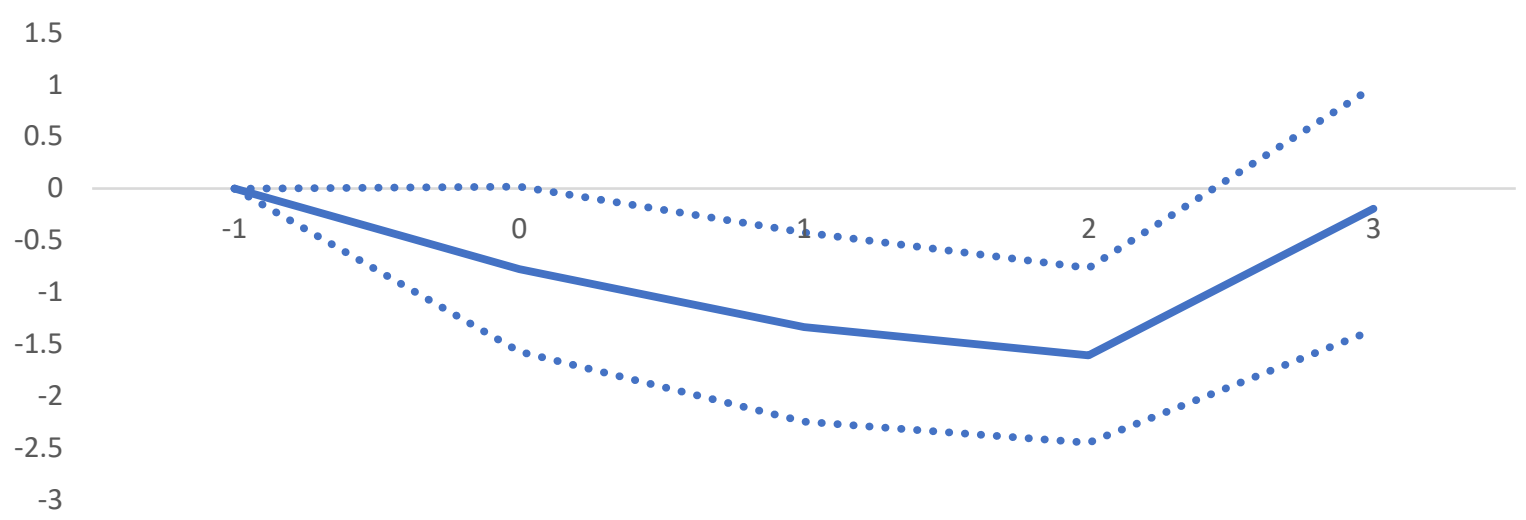

Panel A. Saving

1.5

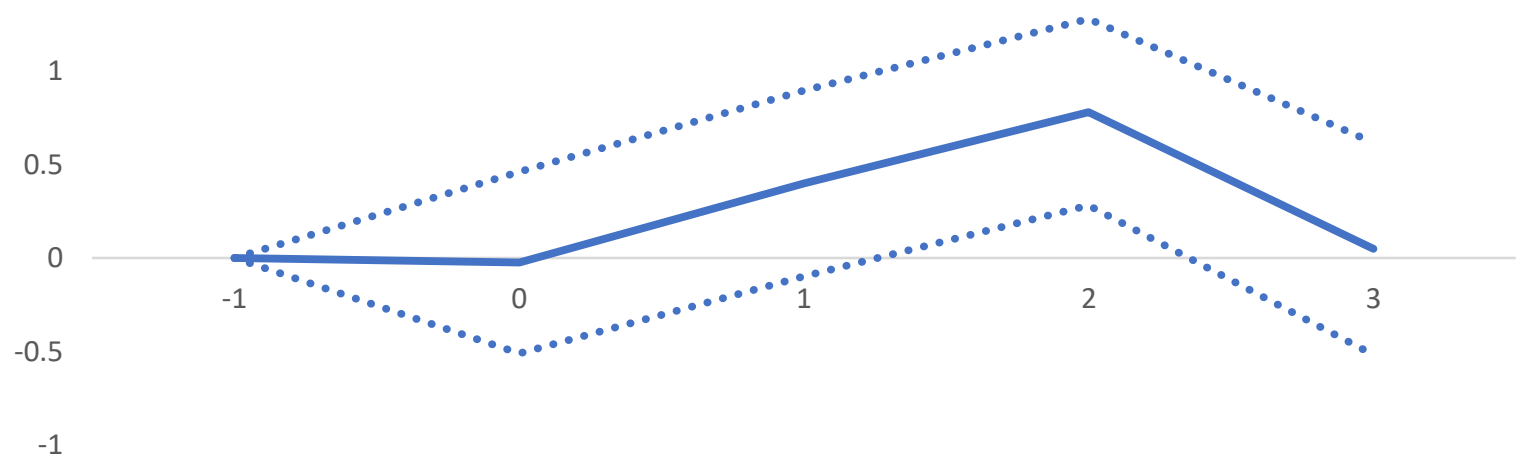

Note: $\mathrm{X}$-axis indicate years after the shock at $\mathrm{t}=0$. Blue lines denote the response of investment and saving to 1 percentage point of GDP exogenous increase in the fiscal balance. Dotted lines 90 percent confidence bands. 
Figure 8. Impact of $\mathrm{CAB}$ changes on Investment and Saving (percentage point of GDP)

Panel A. Investment

0.5

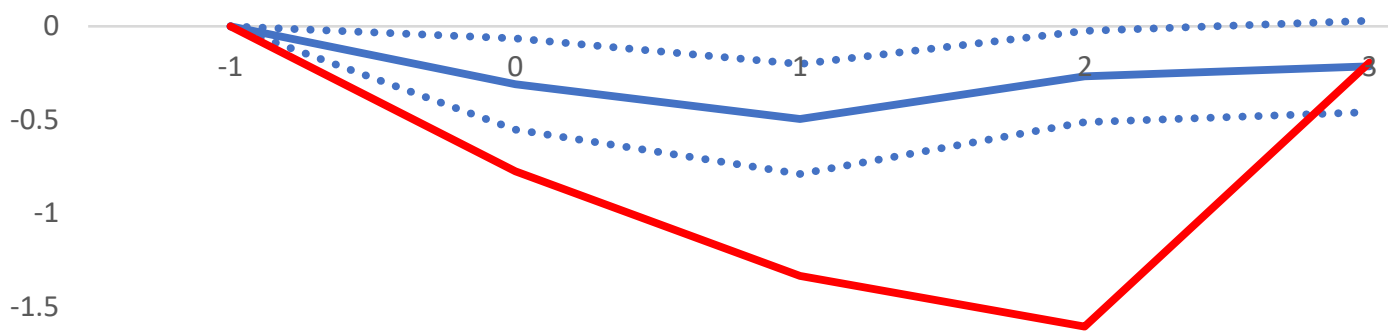

$-2$

Panel B. Saving

1

0.5

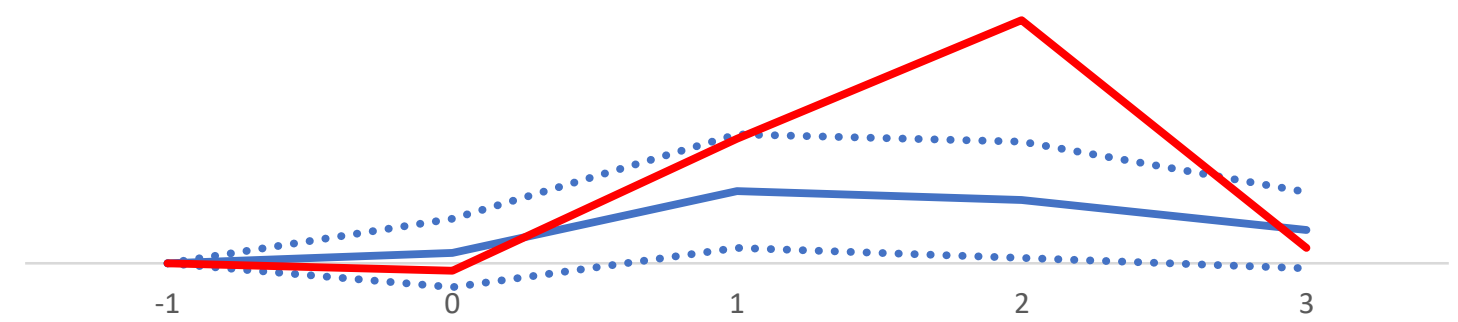

$-0.5$

Note: $\mathrm{X}$-axis indicate years after the shock at $\mathrm{t}=0$. Blue lines denote the response of investment and saving to 1 percentage point of GDP increase in the CAB. Dotted lines 90 percent confidence bands. Red lines denote the response of investment and saving to exogenous shocks reported in Figure 7. 
Figure 9. Impact of Fiscal Shocks on the Current Account Balance: recessions vs. expansions

(percentage point of GDP)

Panel A. Recessions

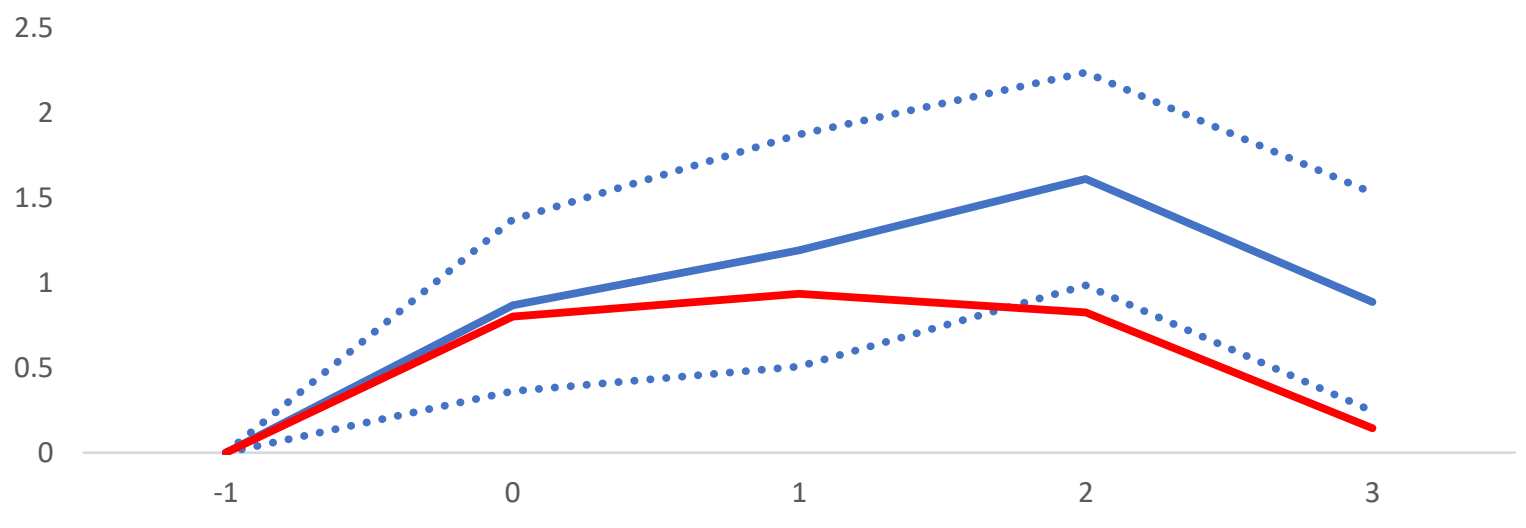

Panel B. Expansions

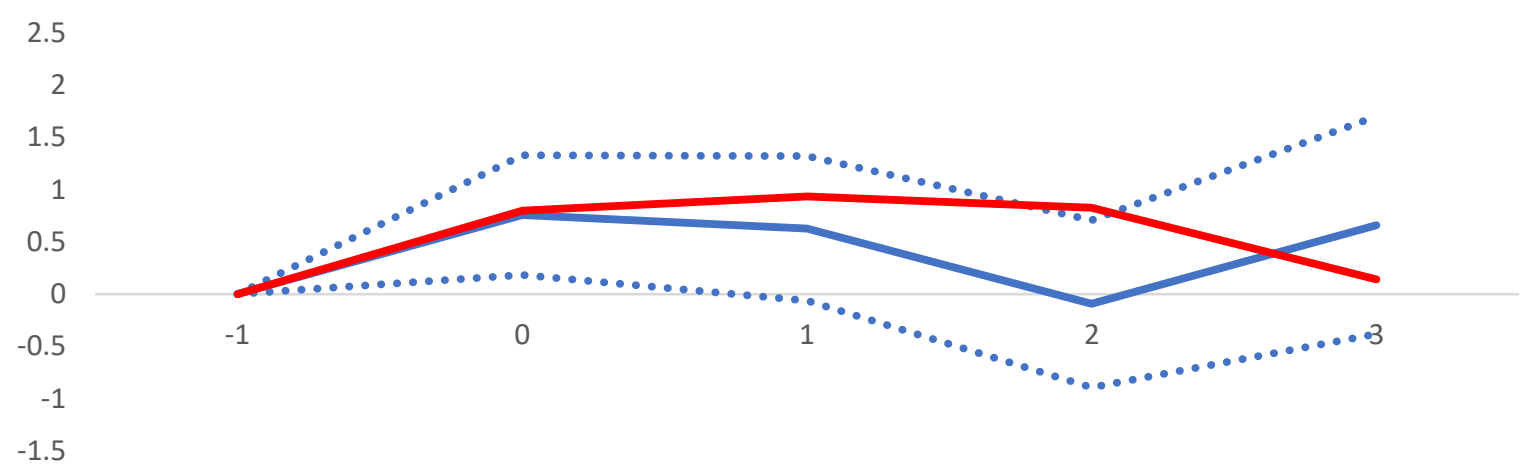

Note: $\mathrm{X}$-axis indicate years after the shock at $\mathrm{t}=0$. Blue lines denote the response of current account to 1 percentage point of GDP exogenous increase in the fiscal balance in the low- (Panel A) versus high-growth (Panel B) regime. Estimates based on Equation (4). Dotted lines 90 percent confidence bands. Red lines indicate the baseline response in Figure 1. 
Figure 10. Impact of Fiscal Shocks on the Current Account Balance-Trade Openness (percentage point of GDP)

\section{Panel A. More Open Economies}

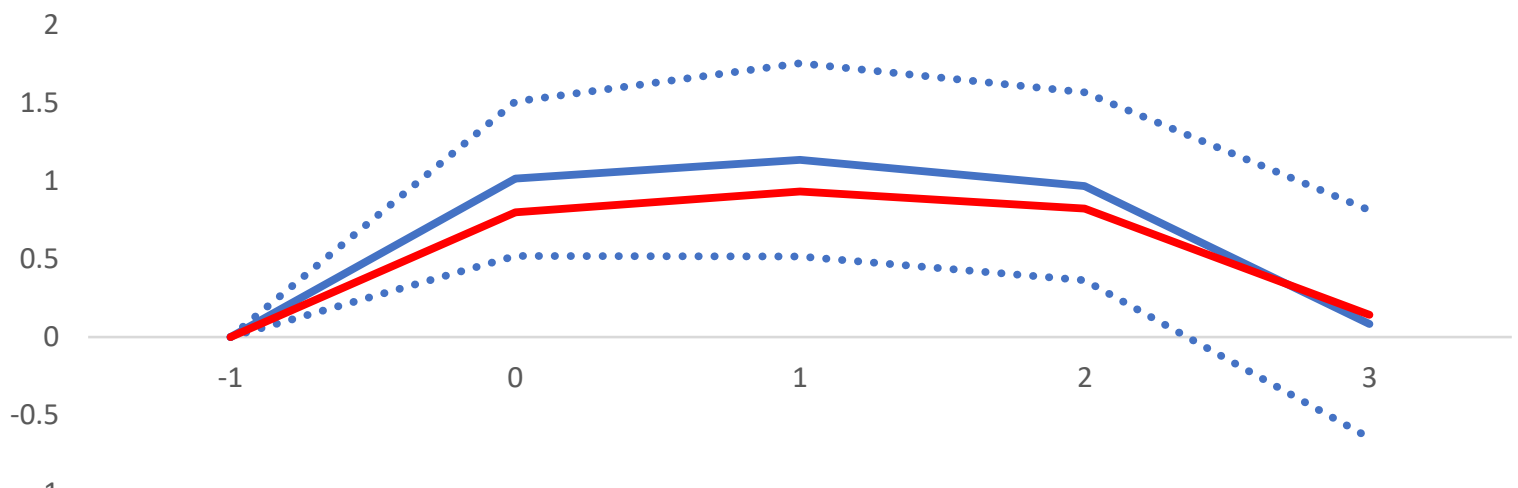

Panel B. Less Open Economies

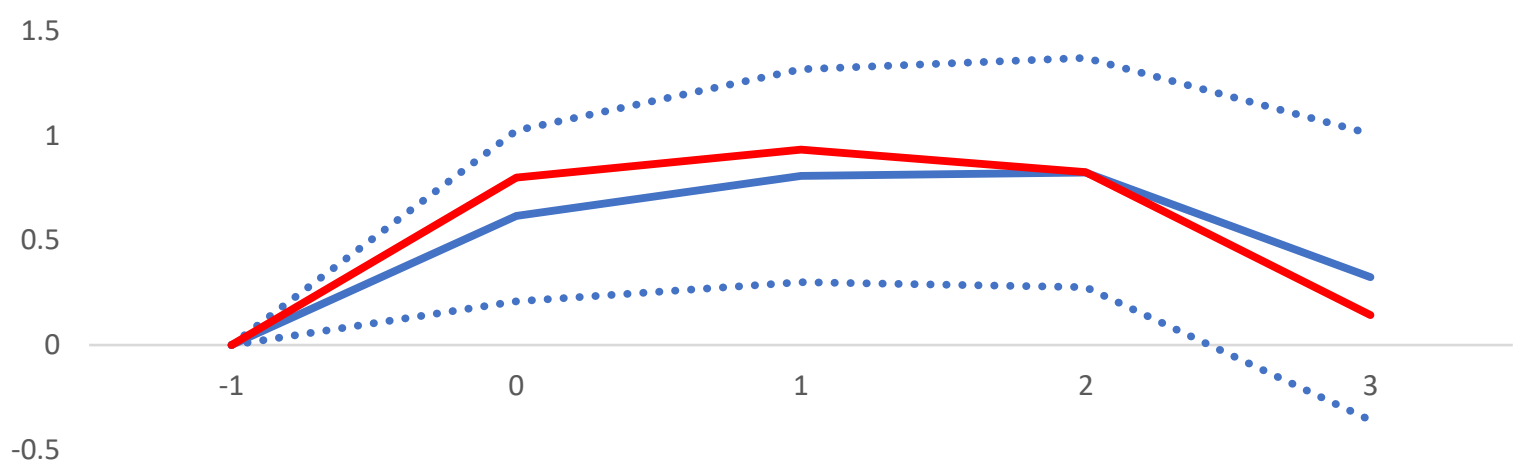

Note: $\mathrm{X}$-axis indicate years after the shock at $\mathrm{t}=0$. Blue lines denote the response of current account to 1 percentage point of GDP exogenous increase in the fiscal balance in more (Panel A) versus less open (Panel B) economies. Estimates based on Equation (5). Dotted lines 90 percent confidence bands. Red lines indicate the baseline response in Figure 1. 
Figure 11. Impact of Fiscal Shocks on the Current Account Balance-Exchange Rate Regimes

(percentage point of GDP)

Panel A. More Flexible Exchange Rate Regimes

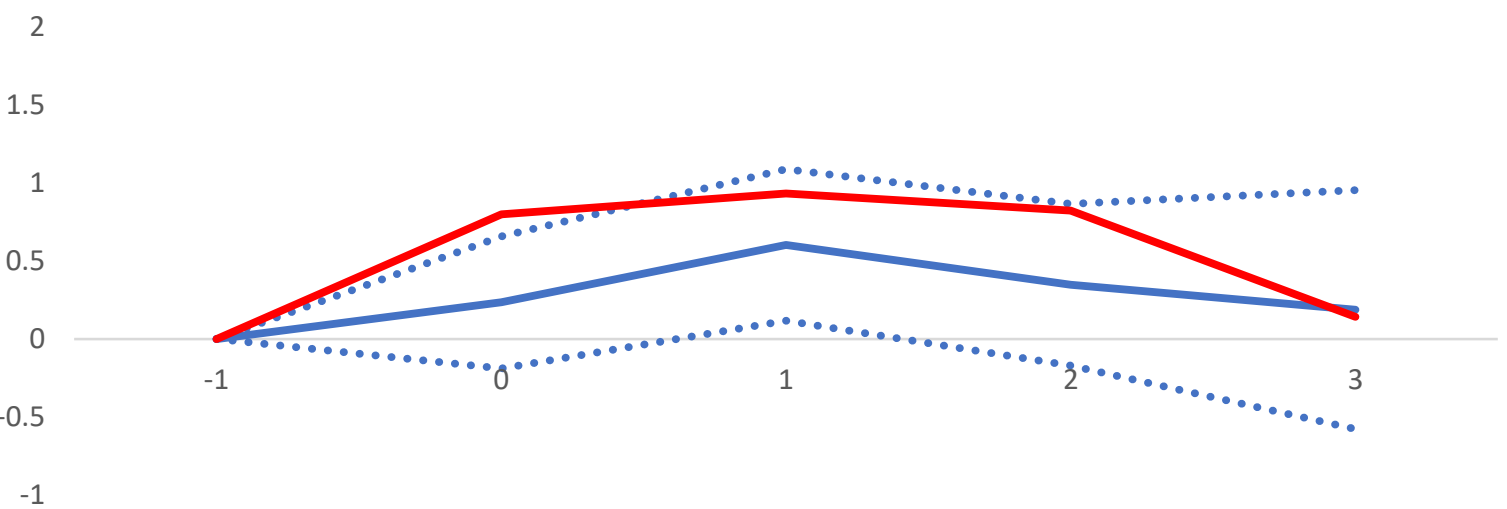

Panel A. Less Flexible Exchange Rate Regimes

2

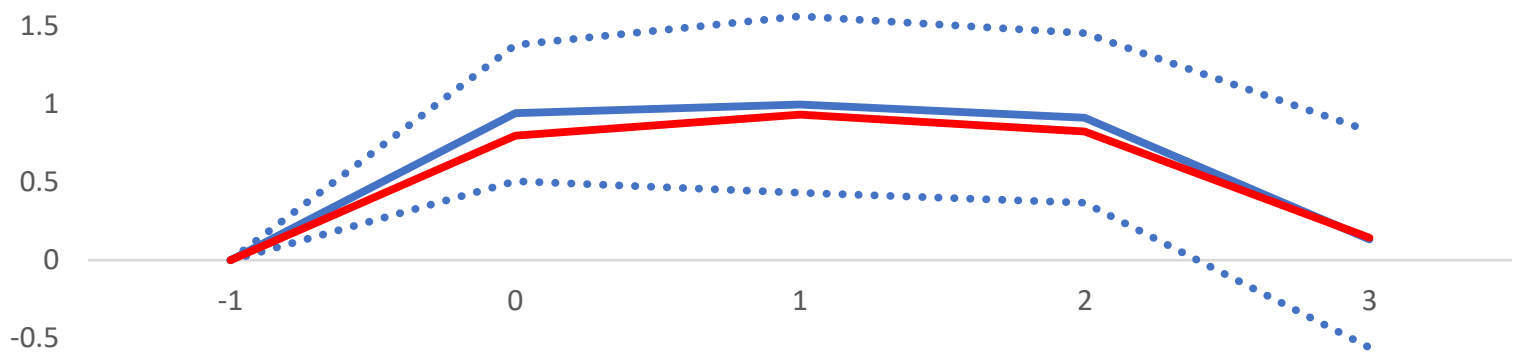

$-1$

Note: $\mathrm{X}$-axis indicate years after the shock at $\mathrm{t}=0$. Blue lines denote the response of current account to 1 percentage point of GDP exogenous increase in the fiscal balance in more (Panel A) versus less flexible (Panel B) exchange rate regimes. Estimates based on Equation (5). Dotted lines 90 percent confidence bands. Red lines indicate the baseline response in Figure 1. 
Figure 12. Impact of Fiscal Shocks on the Current Account Balance-Public Debt (percentage point of GDP)

Panel A. Higher Initial Public Debt-to-GDP ratio

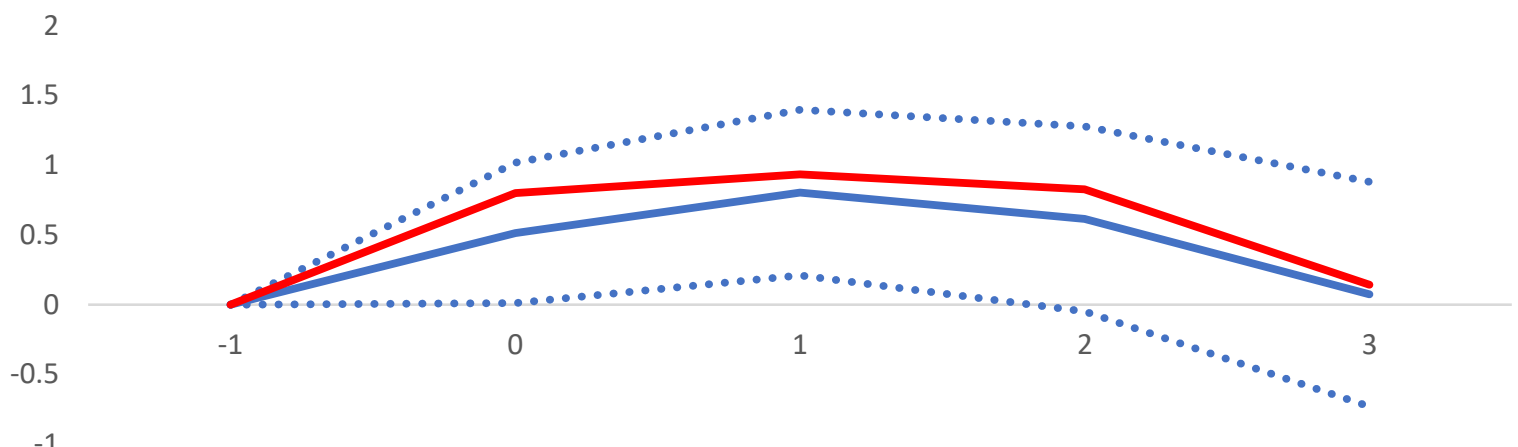

Panel B. Lower Initial Public Debt-to-GDP ratio

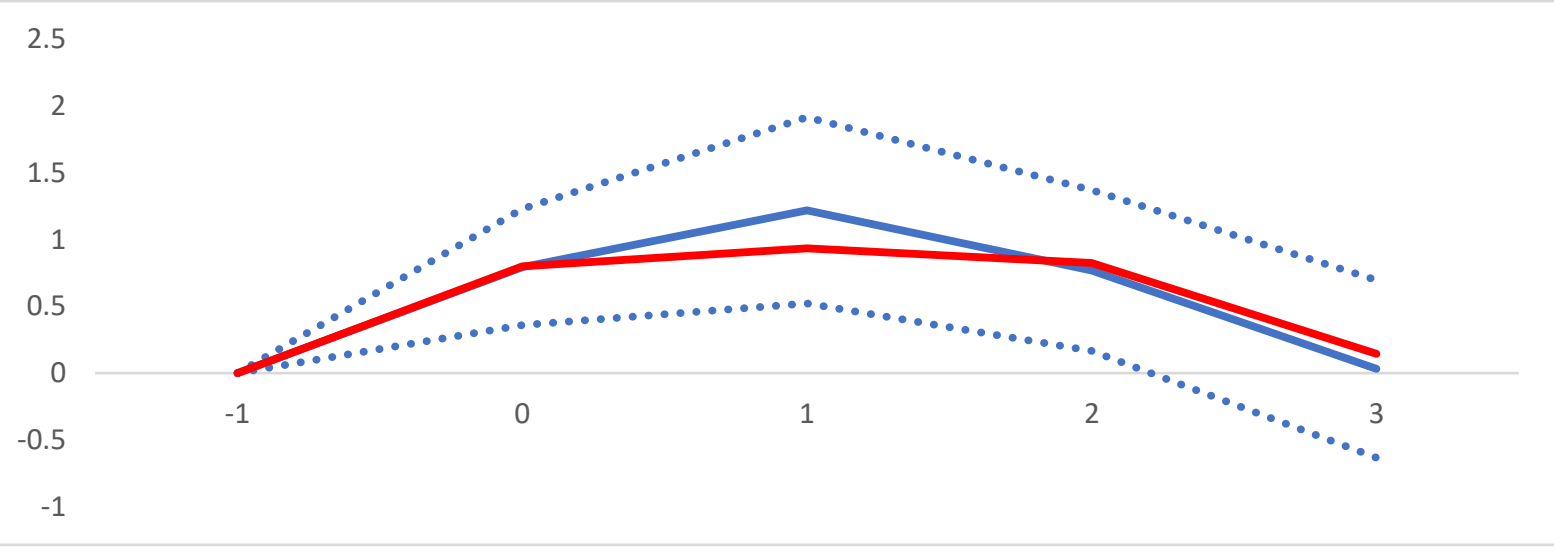

Note: $\mathrm{X}$-axis indicate years after the shock at $\mathrm{t}=0$. Blue lines denote the response of current account to 1 percentage point of GDP exogenous increase in the fiscal balance in higher (Panel A) versus lower (Panel B) public debt-to-GDP ratios. Estimates based on Equation (5). Dotted lines 90 percent confidence bands. Red lines indicate the baseline response in Figure 1. 


\section{APPENDIX}

Table A1. Government Expenditure Shocks in EMDEs

\begin{tabular}{|c|c|c|c|}
\hline country & Mean shock & SD. Shock & $\begin{array}{l}\text { Mean square } \\
\text { forecast error }\end{array}$ \\
\hline Afghanistan & 0.072 & 0.536 & 0.266 \\
\hline Albania & 0.001 & 0.261 & 0.064 \\
\hline Algeria & -0.062 & 0.190 & 0.038 \\
\hline Angola & 0.164 & 0.599 & 0.367 \\
\hline Argentina & 0.039 & 0.288 & 0.079 \\
\hline Armenia & -0.038 & 0.282 & 0.073 \\
\hline Bahrain & -0.084 & 0.285 & 0.084 \\
\hline Bangladesh & 0.017 & 0.133 & 0.017 \\
\hline Barbados & -0.030 & 0.391 & 0.146 \\
\hline Belize & 0.119 & 0.318 & 0.110 \\
\hline Benin & -0.091 & 0.266 & 0.076 \\
\hline Bhutan & -0.110 & 0.263 & 0.067 \\
\hline Bolivia & 0.086 & 0.123 & 0.022 \\
\hline Bosnia and Herzegovina & -0.062 & 0.240 & 0.057 \\
\hline Botswana & 0.009 & 0.263 & 0.066 \\
\hline Brazil & 0.048 & 0.151 & 0.024 \\
\hline Bulgaria & 0.023 & 0.136 & 0.018 \\
\hline Burkina Faso & 0.089 & 0.370 & 0.139 \\
\hline Burundi & -0.023 & 0.487 & 0.226 \\
\hline Cabo Verde & -0.040 & 0.326 & 0.102 \\
\hline Cambodia & 0.113 & 0.166 & 0.039 \\
\hline Cameroon & -0.069 & 0.278 & 0.077 \\
\hline Central African Republic & -0.224 & 0.613 & 0.408 \\
\hline Chad & 0.098 & 0.340 & 0.114 \\
\hline Chile & -0.044 & 0.101 & 0.012 \\
\hline China & -0.043 & 0.055 & 0.005 \\
\hline Colombia & 0.112 & 0.251 & 0.073 \\
\hline Comoros & -0.098 & 0.314 & 0.104 \\
\hline Congo, Democratic Republic of the & -0.203 & 0.778 & 0.615 \\
\hline Congo, Republic of & 0.064 & 0.624 & 0.378 \\
\hline Costa Rica & -0.002 & 0.224 & 0.047 \\
\hline Côte d'Ivoire & -0.064 & 0.293 & 0.085 \\
\hline Croatia & 0.105 & 0.334 & 0.117 \\
\hline Djibouti & -0.049 & 0.351 & 0.120 \\
\hline Dominican Republic & 0.372 & 0.743 & 0.651 \\
\hline Ecuador & 0.026 & 0.211 & 0.042 \\
\hline
\end{tabular}




\begin{tabular}{|c|c|c|c|}
\hline country & Mean shock & SD. Shock & $\begin{array}{l}\text { Mean square } \\
\text { forecast error }\end{array}$ \\
\hline Egypt & -0.015 & 0.076 & 0.006 \\
\hline El Salvador & -0.065 & 0.221 & 0.051 \\
\hline Equatorial Guinea & 0.346 & 0.720 & 0.610 \\
\hline Eritrea & -0.140 & 0.428 & 0.190 \\
\hline Ethiopia & 0.099 & 0.313 & 0.102 \\
\hline Gabon & 0.055 & 0.419 & 0.171 \\
\hline Gambia, The & -0.051 & 0.437 & 0.181 \\
\hline Georgia & 0.023 & 0.145 & 0.018 \\
\hline Ghana & 0.067 & 0.375 & 0.139 \\
\hline Guatemala & -0.018 & 0.244 & 0.055 \\
\hline Guinea & -0.079 & 0.634 & 0.389 \\
\hline Guinea-Bissau & 0.020 & 0.834 & 0.661 \\
\hline Haiti & 0.095 & 0.338 & 0.116 \\
\hline Honduras & 0.029 & 0.269 & 0.070 \\
\hline India & -0.032 & 0.086 & 0.008 \\
\hline Indonesia & 0.002 & 0.103 & 0.010 \\
\hline Iran & -0.008 & 0.277 & 0.073 \\
\hline Jordan & -0.168 & 0.336 & 0.118 \\
\hline Kazakhstan & -0.021 & 0.178 & 0.029 \\
\hline Kenya & 0.040 & 0.231 & 0.053 \\
\hline Kuwait & 0.037 & 0.368 & 0.131 \\
\hline Lebanon & -0.198 & 0.325 & 0.138 \\
\hline Lesotho & -0.092 & 0.289 & 0.089 \\
\hline Lithuania & -0.036 & 0.201 & 0.039 \\
\hline Madagascar & -0.125 & 0.393 & 0.164 \\
\hline Malawi & 0.004 & 0.216 & 0.043 \\
\hline Malaysia & 0.057 & 0.122 & 0.017 \\
\hline Maldives & 0.034 & 0.388 & 0.145 \\
\hline Mali & 0.007 & 0.367 & 0.126 \\
\hline Mauritius & -0.068 & 0.305 & 0.094 \\
\hline Mexico & 0.031 & 0.134 & 0.018 \\
\hline Moldova & 0.005 & 0.317 & 0.094 \\
\hline Mongolia & 0.038 & 0.403 & 0.156 \\
\hline Montenegro, Rep. of & -0.176 & 0.374 & 0.153 \\
\hline Morocco & 0.040 & 0.144 & 0.022 \\
\hline Mozambique & -0.061 & 0.208 & 0.045 \\
\hline Myanmar & 0.114 & 0.186 & 0.046 \\
\hline Namibia & -0.048 & 0.273 & 0.073 \\
\hline Nepal & 0.098 & 0.216 & 0.051 \\
\hline Nicaragua & 0.052 & 0.207 & 0.043 \\
\hline
\end{tabular}

CInternational Monetary Fund. Not for Redistribution 


\begin{tabular}{|c|c|c|c|}
\hline country & Mean shock & SD. Shock & $\begin{array}{l}\text { Mean square } \\
\text { forecast error }\end{array}$ \\
\hline Niger & -0.062 & 0.297 & 0.088 \\
\hline Nigeria & -0.075 & 0.364 & 0.129 \\
\hline Oman & -0.059 & 0.179 & 0.033 \\
\hline Pakistan & 0.051 & 0.190 & 0.037 \\
\hline Panama & 0.054 & 0.136 & 0.020 \\
\hline Paraguay & 0.012 & 0.278 & 0.074 \\
\hline Peru & -0.042 & 0.163 & 0.027 \\
\hline Philippines & -0.040 & 0.188 & 0.035 \\
\hline Poland & 0.024 & 0.139 & 0.015 \\
\hline Romania & -0.106 & 0.254 & 0.073 \\
\hline Russia & 0.006 & 0.318 & 0.095 \\
\hline Rwanda & -0.061 & 0.308 & 0.094 \\
\hline São Tomé and Príncipe & -0.134 & 0.299 & 0.100 \\
\hline Saudi Arabia & 0.139 & 0.324 & 0.119 \\
\hline Senegal & 0.013 & 0.175 & 0.029 \\
\hline Serbia & -0.048 & 0.135 & 0.019 \\
\hline Seychelles & 0.103 & 0.540 & 0.290 \\
\hline Sierra Leone & -0.027 & 0.428 & 0.171 \\
\hline South Africa & -0.001 & 0.099 & 0.009 \\
\hline Sri Lanka & 0.040 & 0.223 & 0.049 \\
\hline Swaziland & -0.008 & 0.256 & 0.062 \\
\hline Tanzania & -0.070 & 0.178 & 0.035 \\
\hline Thailand & -0.053 & 0.096 & 0.012 \\
\hline Togo & -0.260 & 0.463 & 0.274 \\
\hline Trinidad and Tobago & -0.040 & 0.374 & 0.136 \\
\hline Tunisia & -0.042 & 0.198 & 0.038 \\
\hline Turkey & 0.129 & 0.173 & 0.045 \\
\hline Turkmenistan & -0.194 & 0.393 & 0.179 \\
\hline Uganda & -0.079 & 0.238 & 0.060 \\
\hline Ukraine & 0.113 & 0.225 & 0.060 \\
\hline United Arab Emirates & 0.046 & 0.226 & 0.050 \\
\hline Uruguay & 0.023 & 0.200 & 0.038 \\
\hline Venezuela & 0.025 & 0.302 & 0.088 \\
\hline Vietnam & 0.107 & 0.209 & 0.052 \\
\hline Yemen & -0.104 & 0.314 & 0.103 \\
\hline Zambia & 0.054 & 0.240 & 0.057 \\
\hline
\end{tabular}

Source: IMF World Economic Outlook and authors calculations. 
Table A2. Mean square error of government spending growth rate forecasts

Country group Mean square forecast error

\begin{tabular}{lc}
\hline AEs & 2.25 \\
EMDEs & 11.9 \\
EMs & 9.9 \\
LICs & 14.9
\end{tabular}

Source: IMF World Economic Outlook and authors calculations.

Note: The group classification is based on the IMF WEO.

Figure A1. Distribution of Government Expenditure Shocks in EMDEs

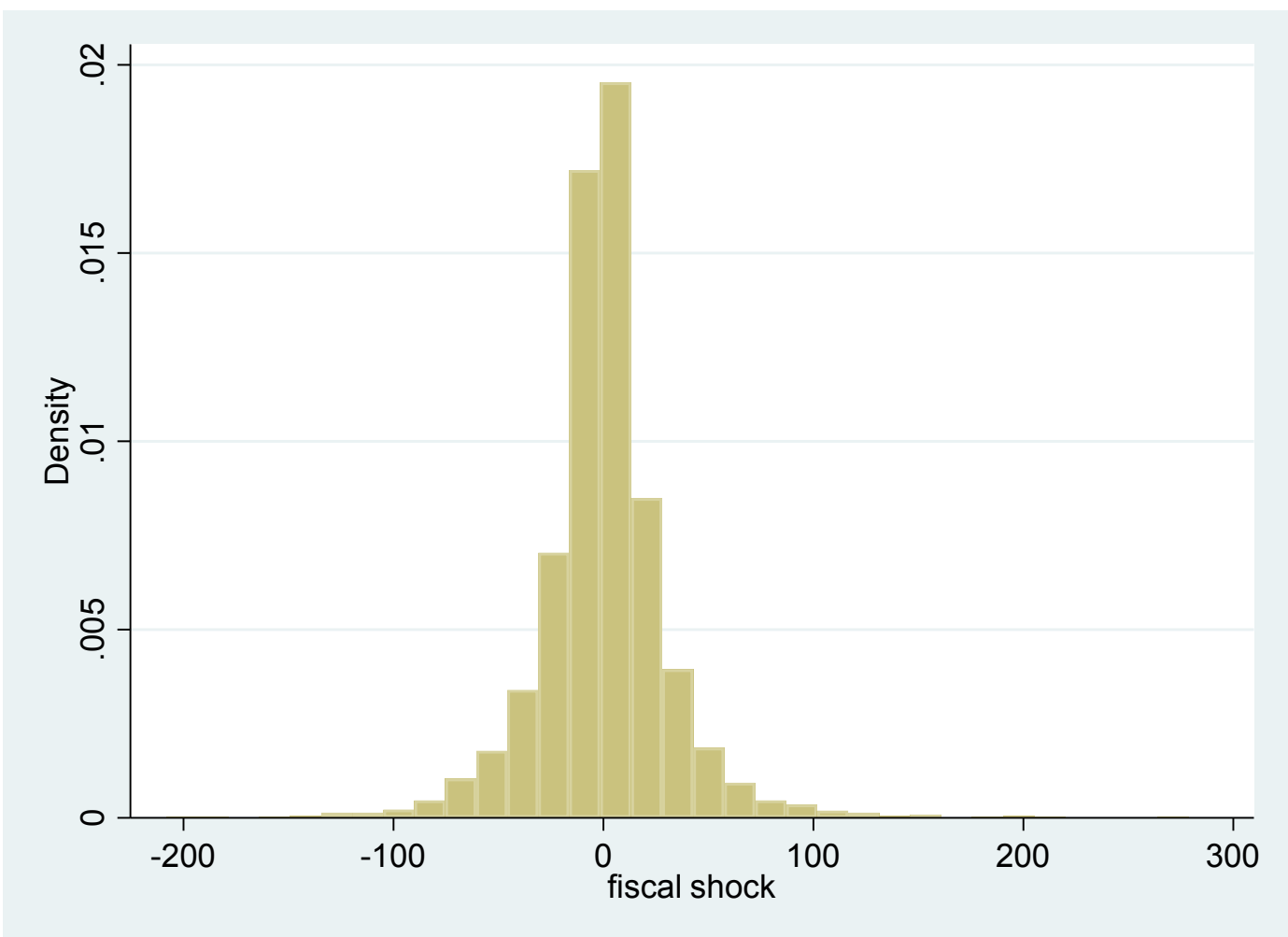

Source: IMF World Economic Outlook and authors calculations. 
Figure A2. Impact of Fiscal Shocks on the Nominal Exchange Rate (percentage)

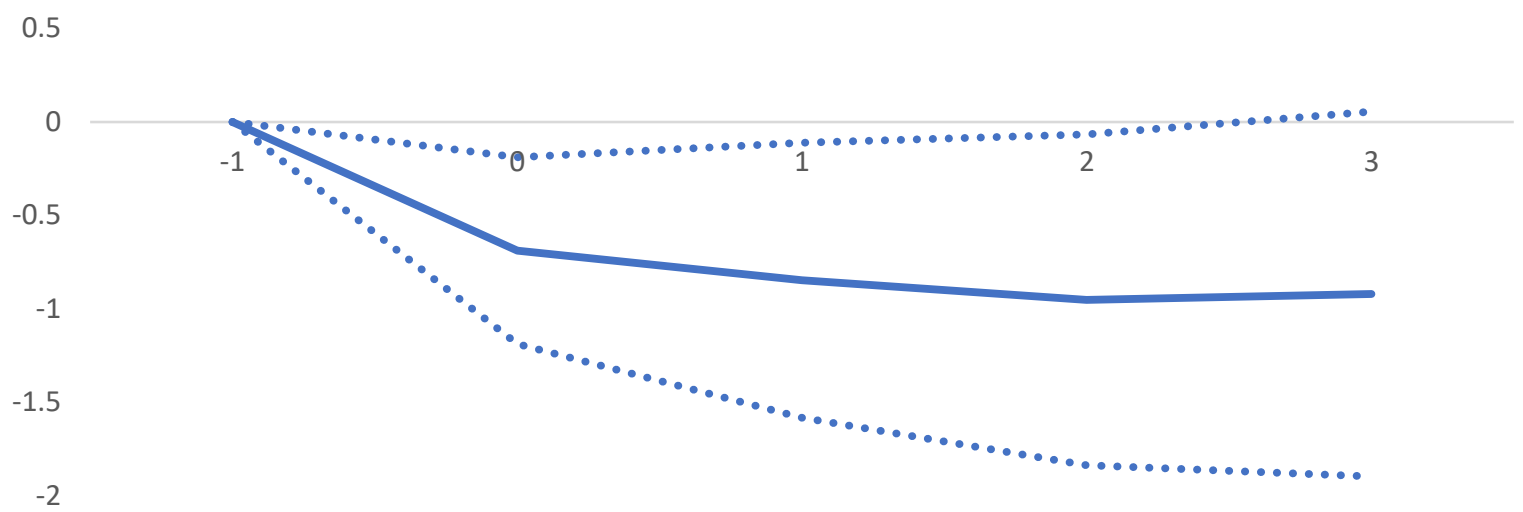

Note: $\mathrm{X}$-axis indicate years after the shock at $\mathrm{t}=0$. Blue lines denote the response of the nominal exchange rate to 1 percentage point of GDP exogenous increase in the fiscal balance. Dotted lines 90 percent confidence bands. Estimates based on Equation (2). 